\title{
Tuning recombinant protein expression to match secretion capacity
}

\author{
Luminita Gabriela Horga ${ }^{1 \dagger}$, Samantha Halliwell ${ }^{1 \dagger}$, Tania Selas Castiñeiras ${ }^{2}$, Chris Wyre ${ }^{2}$, Cristina F. R. O. Matos ${ }^{2}$, \\ Daniela S. Yovcheva ${ }^{2}$, Ross Kent ${ }^{1}$, Rosa Morra', Steven G. Williams², Daniel C. Smith ${ }^{2}$ and Neil Dixon ${ }^{1 *}$ (D)
}

\begin{abstract}
Background: The secretion of recombinant disulfide-bond containing proteins into the periplasm of Gram-negative bacterial hosts, such as E. coli, has many advantages that can facilitate product isolation, quality and activity. However, the secretion machinery of $E$. coli has a limited capacity and can become overloaded, leading to cytoplasmic retention of product; which can negatively impact cell viability and biomass accumulation. Fine control over recombinant gene expression offers the potential to avoid this overload by matching expression levels to the host secretion capacity.
\end{abstract}

Results: Here we report the application of the RiboTite gene expression control system to achieve this by finely controlling cellular expression levels. The level of control afforded by this system allows cell viability to be maintained, permitting production of high-quality, active product with enhanced volumetric titres.

Conclusions: The methods and systems reported expand the tools available for the production of disulfide-bond containing proteins, including antibody fragments, in bacterial hosts.

Keywords: Periplasmic secretion, Antibody fragments, Riboswitches, Codon usage, Signal peptides

\section{Background}

Microbial cells have evolved phenotypic traits and cellular functions matched to their endogenous environmental niches; however they have not necessarily evolved with the cellular production capacity requirements often demanded in a biotechnological context. With respect to recombinant protein production, host cells are required to produce large quantities of heterologous protein, but may not exhibit the appropriate intracellular processing capacity to match this biotechnological demand imposed upon them. For example, they may not exhibit the required cellular synthetic capacity, folding capacity or indeed secretion capacity. In such scenarios high levels of recombinant protein production overload the host's capacity resulting in deleterious outcomes for the recombinant protein and/or the production host [1-7].

\footnotetext{
*Correspondence: neil.dixon@manchester.ac.uk

${ }^{\dagger}$ Luminita Gabriela Horga and Samantha Halliwell contributed equally to this work

${ }^{1}$ Manchester Institute of Biotechnology, School of Chemistry, University of Manchester, Manchester M1 7DN, UK

Full list of author information is available at the end of the article
}

A number of potential solutions are available to address these imbalances: (i) increase the host's capacity, e.g. by overexpression of endogenous genes encoding helpers proteins such as chaperones, secretion machinery, and ancillary factors, (ii) add new capability e.g. expression of heterologous genes encoding helper proteins, or (iii) seek to match expression demand with the host's capacity [3, 8-11].

Secretion of recombinant protein offers a number of potential advantages. By allowing segregation of the protein product away from the cytoplasmic components to (i) reduce the chance of any deleterious interactions of the recombinant protein with the host and reduce molecular crowding effects, (ii) reduce the exposure of the recombinant protein to host cytoplasmic proteases, (iii) aid disulfide bond formation, away from reducing cytoplasmic environment, and (iv) produce recombinant proteins with a true $\mathrm{N}$-terminus (absence of methionine). In Gram-negative bacteria protein secretion across the inner membrane into the periplasmic space occurs predominantly via the SecYEG translocon [12]. Pre-proteins containing a $\mathrm{N}$-terminal signal sequence 
(signal peptides), of 18-30 amino acids in length, target the proteins for secretion [13]. The hydrophobicity of the signal peptide determines whether secretion occurs via the SecB-dependent or the signal recognition particle-dependent (SRP) pathway [14]. The classical distinction is that translocation via the SecB path occurs post translation, and the SRP path via co-translation. Both the SecB and SRP pathways maintain the pre-protein in an unfolded 'translocation-competent state' [15]. Both pathways involve 3 key steps, (i) sorting and targeting, (ii) translocation, and (iii) release. The efficiency of each step is dependent upon the dynamic, transient interactions between the target protein and the various stages of the respective pathways, and hence secretion efficiency is highly dependent upon the biophysical characteristics of the recombinant protein $[12,14,15]$.

Although Sec-dependent secretion is widely used, there are well-documented examples where the secretion machinery becomes overloaded and the Sec translocon becomes 'jammed' resulting in accumulation of the target protein in the cytoplasm and cell toxicity [16]. Above a certain optimal rate of translation, secretion rates can rapidly decrease [17]. This is most likely due to the limited secretion capacity of the $E$. coli transport machinery compared to the rate of translation [5]. When this secretion capacity is overwhelmed, the excess target protein is likely to accumulate in inclusion bodies, affecting protein titres and cell viability, highlighting the need to carefully optimize expression levels and rate of recombinant protein production [18].

The commonly employed inducible bacterial expression systems mostly operate at the transcriptional level. For instance, lactose or arabinose regulated systems generate a heterogeneous cell population upon induction, where some cells are fully induced and other cells remain un-induced [19, 20]. Tuneable expression systems can address some of these limitations by modulation of gene expression to adjust to the physiological needs of the bacterial host and provide optimal parameters for recombinant protein production [21, 22]. The RiboTite technology has been demonstrated to robustly control the expression of a variety of recombinant genes encoding therapeutic proteins in E. coli, and provides cellular level titratable control of gene expression and very tight control of basal gene expression in the absence of induction [23]. The system operates at both the transcription and translation level to afford a gene regulatory cascade, by using an inducible promoter-operator-repressor (IPTG, $\mathrm{P} / \mathrm{O}_{\mathrm{lac}}$, lacI), and a small molecule Pyrimido-pyrimidine-2,4diamine (PPDA) inducible translational ON orthogonal riboswitch (ORS), to control both a chromosomal copy of T7 RNAP and an episomal copy of recombinant gene of interest (GOI) (Fig. 1a).
Production of therapeutically important proteins such as cytokines and antibody fragments in E. coli commonly employs the SecYEG translocon to secrete the proteins into the periplasmic space $[24,25]$. Antibody fragments are truncated and engineered versions of antibodies, usually derived from the IgG isotype, contain the complementarity-determining regions (CDRs) that retain binding capacity to specific antigens [26]. A single chain $\mathrm{Fv}(\mathrm{scFv})$ consists of heavy and light chain association through a short synthetic peptide linker. Antibody fragments have extensive applications for diagnostics and detection of a wide repertoire of agents, as well as for therapeutic treatment of a range of health disorders [27]. A range of $\mathrm{scFv}$ agents and derivatives are currently in clinical trials, with one anti-VEGF scFv that successfully completed Phase III trials in 2017 [28, 29]. In this study, we explored whether the precise control of gene expression offered by the RiboTite system would avoid the previously observed overload of the Sec translocon [5, 16], and permit isolation of protein with increased product quality, activity and titres.

\section{Results}

Concept and workflow of applying the RiboTite expression system for titratable secretion

The RiboTite expression system [23] was employed in order to regulate SecYEG-dependent secretion of single chain antibody fragments ( $\mathrm{scFv}$ ) into the periplasm of E. coli (Fig. 1b). Here expression plasmids were constructed where the gene of interest (GOI) was placed in-frame with sfGFP to generate a fusion protein (pENTRY) (Fig. 1c). The pENTRY permits rapid evaluation and selection of signal sequence variants from a synonymous codon library. Following selection of variants with enhanced expression and regulatory performance, the fusion protein was removed by sub-cloning the GOI into pDEST plasmid and secretion performance was assessed. The selected clones were then assessed under fed-batch fermentation control to validate their performance under high cell density culture conditions. In this study we utilised the single chain antibody fragments anti- $\beta$ galactosidase $(\operatorname{scFv} \beta)$ [30], anti-histone $(\mathrm{scFvH})$ [31], and anti-tetanus (scFvT) [32].

\section{Design and construction of the expression strain and plasmids}

In this study expression strains and plasmids were developed to simultaneously achieve enhanced basal control and integration of the $5^{\prime}$ encoded signal peptide sequence respectively. The $E$. coli expression strain BL21(LV2), was designed from the previously reported BL21(IL3) strain [23], by (i) replacing the repressor gene with a stronger repressor $\left(\operatorname{lacI}^{q}\right)$, (ii) 


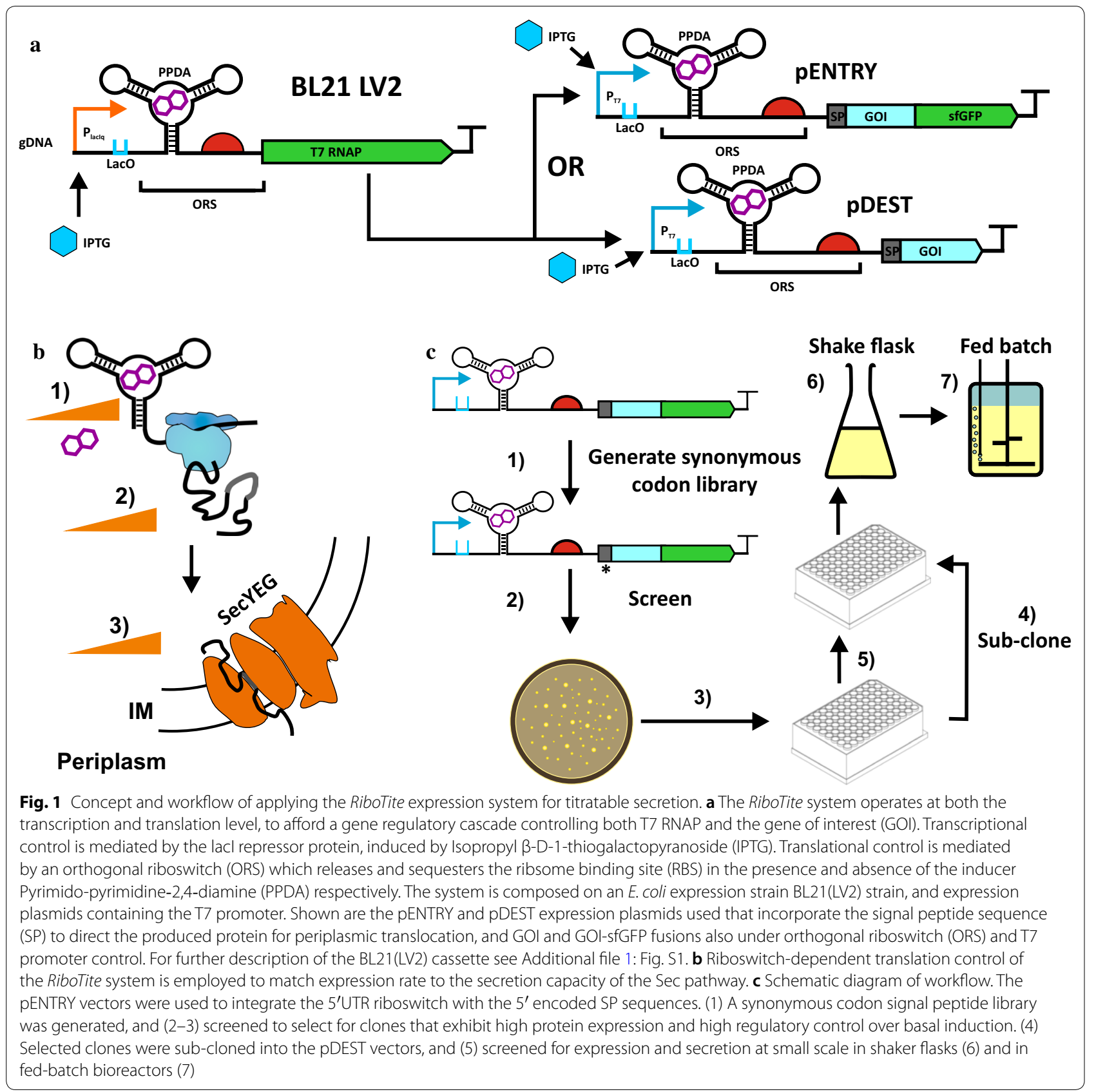

inverting its orientation to the opposite direction to the T7 RNAP gene, and (iii) incorporating an additional operator $(\mathrm{O} 3)$ to further tighten the basal expression (Additional file 1: Fig. S1). To assess this modification we benchmarked performance of various T7 RNAP-dependent strains for expression and regulatory control (Additional file 1: Table S1, Fig. S2). The analysis was performed by monitoring expression of eGFP (cytoplasmic) under different induction conditions, times and growth media. The BL21(LV2) strain demonstrated total expression comparable to the most commonly used expression strain BL21(DE3), but with significantly greater regulatory control (>1000-fold vs. 30-fold) in the presence of the respective inducers, and was used for all subsequent analysis.

Expression-secretion plasmids (pENTRY, pDEST) were designed to direct the produced recombinant protein towards the SecYEG translocon for periplasmic secretion. Four different signal peptide encoding sequences (SP) were cloned upstream of the GOI: two 
SecB-dependent signal peptides (Piii and PelB) and two SRP-dependent signal peptides (DsbA and yBGL2) [33, 34].

\section{Integration of signal peptide sequences with the regulatory RiboTite system permits tuneable control of gene expression}

The performance of cis-encoded regulatory RNA devices is known to be highly sensitive to flanking nucleotide sequence and structure [35, 36]. This poor modulatory limits the facile integration of RNA devices, e.g. riboswitches into alternative coding contexts. Close to an open reading frame RNA regulatory performance e.g. translation initiation from the ribosome-binding site (RBS) has been shown to be sensitive to secondary structure in the $5^{\prime}$ coding region [37-39]. Building on this approach we recently developed a riboswitch integration method that permits selection of codon variants with expanded riboswitch-dependent regulatory control over gene expression [40]. To optimise the regulatory performance of the cisencoded translation ON riboswitch located in the $5^{\prime} \mathrm{UTR}$ and $5^{\prime}$ encoded signal peptide sequences, the recently developed codon context integration method was used [40]. The method is based on the introduction of synonymous codons immediately downstream from the start codon; this conserves the amino acid sequence of the resulting signal peptide that interacts with the secretory apparatus (i.e. SRP or SecB), whilst permitting codon usage and RNA folding space to be explored.

The synonymous codon libraries encoding the signal peptides of interest were generated by site directed mutagenesis, to produce variants at codons 2 through to 6 using pENTRY (Additional file 1: Table S2). The theoretical library sizes ranged from 48 to 256 variants dependent on the specific signal peptides, sufficient colonies were screened to ensure $95 \%$ coverage (>3-times theoretical size per library), using the BL21(LV2) expression strain. Hits were selected on the basis of expanded riboswitch-dependent expression control relative to the starting (WT) sequence. Strains with the selected codon-optimised and WT signal peptide sequences were treated with increasing inducer concentration to assess expression and titratability (Additional file 1: Fig. S3). All selected codon variant strains exhibited higher maximum expression compared to their respective WT. Most variants showed a modest increase of maximum expression (up to twofold), whereas the Piii-E5 variant showed the highest expression increase, 577-fold higher than the strain with the WT signal peptide (Table 1). In the absence of any inducer, all strains showed minimal fluorescence signal. Expression in the presence of only the transcriptional inducer $(\mathrm{IPTG}=150 \mu \mathrm{M})$ was reduced relative to wild type for the SRP-dependent pathway, whereas the reverse was observed for SecB-dependent signal peptides. In terms of regulatory performance the strain with the Piii-E5 signal peptide exhibited the largest dynamic range both for riboswitch-dependent control (IP/I) (16-fold), and total expression control (IP/UI) (127fold) (Fig. 2a). The strains with DsbA-E1 and yBGL2-H1 also presented good riboswitch-dependent control of expression (IP/I) of 11- fold and 13-fold, and total expression control (IP/UI) 33-fold and 60-fold respectively. This is in comparison to other inducible T7 RNAP expression systems that have been reported to display twofold expression control of secretion [41]. All strains with codon optimised signal peptide constructs were PPDAtitratable and showed improved expression and titratability compared to WT constructs indicating a good integration of the riboswitch (Additional file 1: Fig. S3).

Due to resource limitation and metabolic burden upon the host, higher protein production usually negatively impacts the cell density of bacterial culture [42,

Table 1 Expression performance of the BL21(LV2)-pENTRY strains containing the codon optimised signal peptide sequences

\begin{tabular}{lllllrrrr}
\hline & Signal peptide & Max (IP) & IPTG (I) & $\begin{array}{l}\text { Uninduced } \\
(\mathbf{U I})\end{array}$ & IP/I & IP/UI & $\begin{array}{l}\text { PPDA concentration } \\
(\boldsymbol{\mu} \text { M) at max (IP) }\end{array}$ & $\begin{array}{l}\text { OD }_{\mathbf{6 0 0}} \text { at max (IP) } \\
\text { SRP-dependent }\end{array}$ \\
& DsbA WT & 1629 & 754 & 64 & 2 & 26 & 8 & $1 \pm 0$ \\
& DsbA E1 & 2152 & 202 & 65 & 11 & 33 & 400 & $18 \pm 5$ \\
& yBG L2 WT & 4017 & 1283 & 75 & 3 & 54 & 8 & $11 \pm 10$ \\
& yBGL2 H1 & 4493 & 336 & 75 & 13 & 60 & 200 & $20 \pm 4$ \\
SecB-dependent & Piii WT & 17 & 21 & 34 & 1 & 0 & 400 & $14 \pm 6$ \\
& Piii E5 & 9818 & 607 & 77 & 16 & 127 & 400 & $24 \pm 3$ \\
& PelB WT & 1297 & 179 & 74 & 7 & 18 & 400 & $21 \pm 2$ \\
& PelB A5 & 2913 & 355 & 76 & 8 & 38 & 100 & $16 \pm 6$ \\
\hline
\end{tabular}



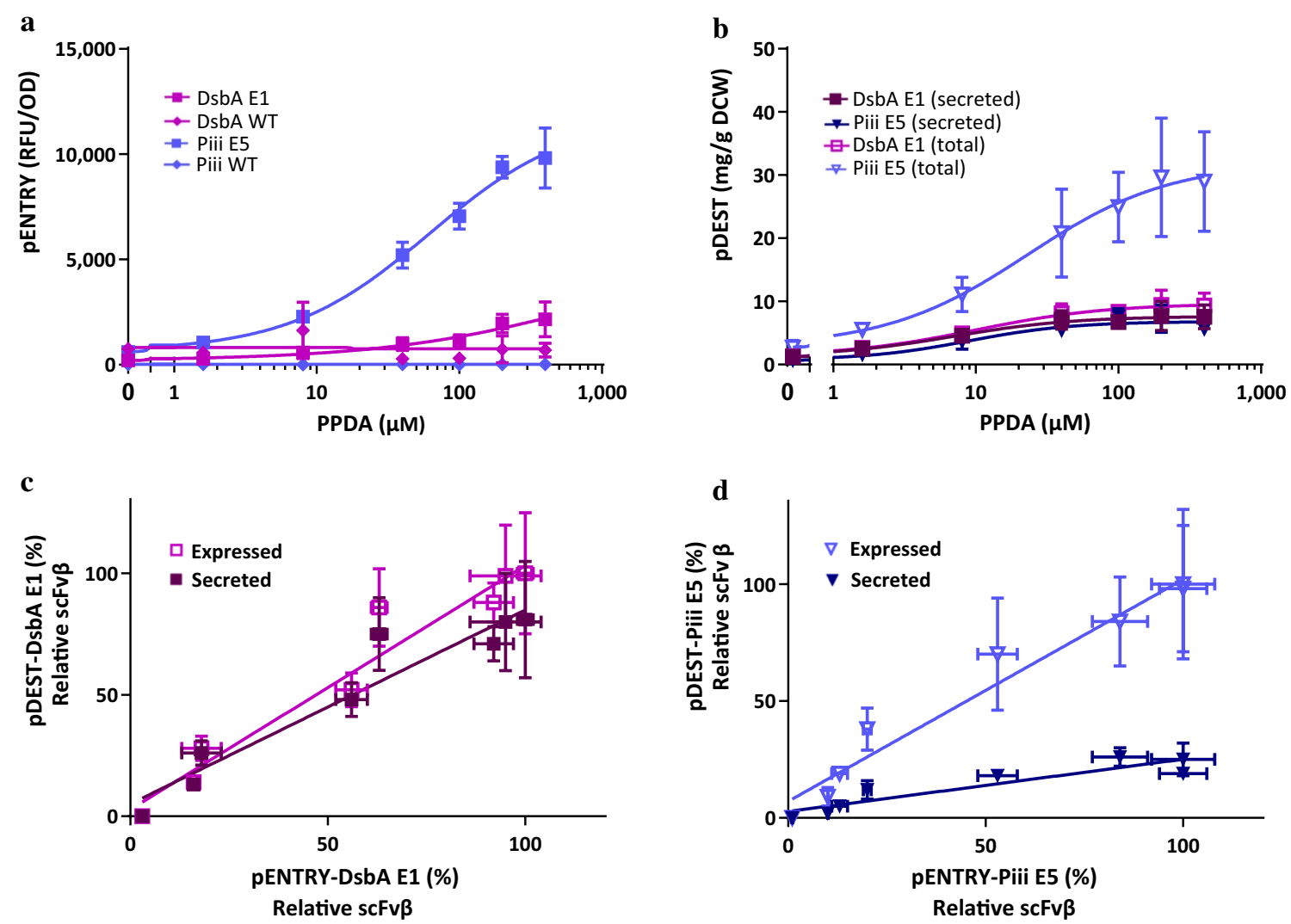

Fig. 2 scFv $\beta$ expresion control and correlation analysis for codon-optimised signal peptide sequences constructs. a Dose response curves for pENTRY constructs, relative fluorescent units normalized to cell density (RFU/OD ${ }_{600}$ ) against inducer concentration for the WT and codon optimised DsbA and Piii signal peptide sequences. b Dose response curves for pDEST constructs, expression yield per cell reported as mg per $\mathrm{g}$ dry cell weight. $\mathbf{c}$ Linear regression of the pENTRY expression vs. PDEST expression for DsbA-E1 and Piii-E5. $\mathbf{d}$ Linear regression of the pENTRY expression vs pDEST secretion for the DsbA E1 and Piii E5. All data was taken from shaker flask expression under different inducer concentrations at $30^{\circ} \mathrm{C}, 14 \mathrm{~h}$ post induction performed in biological triplicates

43]. However, strains containing codon-optimised signal peptides DsbA-E1 and Piii-E5, both displayed increased biomass $\left(\mathrm{OD}_{600}\right)$ and higher expression per cell (RFU/OD) than the respective strains with WT signal peptides. Indeed induction dependent inhibition of cell growth was more prominent for the WT signal peptides (Additional file 1: Fig. S3). This observation seems to indicate that the optimised signal peptides permit more efficient expression and reduced host burden. Both the SecB-dependent (Piii-E5) and the SRPdependent (DsbA-E1) constructs, displayed significant improvements, in terms of expression and control, over their respective constructs with wild-type signal sequences (Fig. 2a). Overall the SecB-dependent Piii-E5 construct presented the highest maximum expression, best regulatory performance and biomass accumulation, while the SRP-dependent DsbA-E1 construct exhibited the best dose response profile (Additional file 1: Fig. S3). The DsbA-E1 and Piii-E5 constructs were selected and sub-cloned (pDEST) to remove the GFP fusion ("Methods" section).

\section{Codon optimised signal peptides permit tuneable expression and secretion of $s c F v \beta$}

Expression and secretion performance of pDEST-scFv $\beta$ containing the DsbA-E1 and Piii-E5 signal peptides was assessed using E. coli BL21(LV2) expression strain following induction at $30{ }^{\circ} \mathrm{C}$ for $14 \mathrm{~h}$ ("Methods" section). Lower maximum protein production per cell (yield), expressed as $\mathrm{mg}$ of recombinant protein per $\mathrm{g}$ of dry cell weight $(\mathrm{mg} / \mathrm{g} \mathrm{DCW})$ was achieved for the strain with the DsbA-E1 signal peptide (9 mg/g DCW) compared to the Piii-E5 (29 mg/g DCW) (Fig. 2b) (Additional file 1: Table S3). Both strains displayed excellent basal control with no detectable production of $\operatorname{scFv} \beta$ in the absence of induction. Further, both strains displayed good riboswitch-dependent (IP/I) control of expression of 7 and 11-fold for DsbA-E1 and Piii-E5 signal peptides 
respectively. In terms of secretion the strain with DsbAE1 displayed a good yield and secretion efficiency ( $7.6 \mathrm{mg} / \mathrm{g}$ and $81 \%$ respectively), whereas the strain with Piii-E5 displayed a slightly lower yield and poorer efficiency $(5.6 \mathrm{mg} / \mathrm{g}$ and $19 \%)$, due to greater total production and retention of $\operatorname{scFv} \beta$ in the spheroplast fraction. Addition of the inducers did not greatly compromise the biomass, with only a small reduction $(15 \%)$ in final $\mathrm{OD}_{600}$ (Additional file 1: Table S3). Both strains displayed good riboswitch-dependent (IP/I) control of secretion of 6 and 13-fold for DsbA-E1 and Piii-E5 respectively, demonstrating that the control afforded by the system permits attenuation of $\mathrm{scFv} \beta$ through the SecYEG translocon both via the SRP and SecB-dependent pathways (Fig. 2b).

Analysis of the half maximal effective concentration $\left(\mathrm{EC}_{50}\right)$ indicates that the expression with DsbA-E1 $(10 \pm 2$ $\mu \mathrm{M})$ is saturated at higher inducer concentration compared to Piii-E5 $(23 \pm 6 \mu \mathrm{M})$. In terms of secretion both signal peptides/pathways displayed similar sensitivity/ saturation $\left(\mathrm{EC}_{50}\right)$, DsbA-E1 $(7 \pm 2 \mu \mathrm{M})$ and Piii-E5 $(9 \pm 6$ $\mu \mathrm{M})$ (Additional file 1: Table S3). Interestingly, this closer matching of the $\mathrm{EC}_{50}$ values between expression and secretion for the DsbA-E1 seems to reflect the greater degree of coordination between translation and secretion of the co-translational SRP pathway [14]. Under these conditions both signal peptides/pathways displayed similar yield, with the co-translation (SRP) pathway performing with greater secretion efficiency (Additional file 1: Table S3). To assess the utility of using the pENTRY (GOI-GFP fusion) plasmid to select signal peptide sequences with optimised codon usage for use in the final secretion pDEST plasmids, we sought to correlate induction-dependent regulatory control from strains with these plasmids (pENTRY vs. pDEST) (Fig. 2c, d). For both signal peptides expression from the scFv-GFP fusion (pENTRY) displayed linear regression coefficient (slope $\sim 1$ ) with total expression of the scFv protein (pDEST). Expression from the pENTRY also displayed close to linear coefficient with secretion pDEST for the DsbA-E1 signal peptide (slope $\sim 0.8$ ), whereas the coefficient with secretion for the Piii-E5 signal peptide was reduced (slope $\sim 0.2$ ).

\section{Performance of codon optimised signal peptides in the absence of translational riboswitch control}

To evaluate and benchmark protein production and secretion in the RiboTite system compared to standard expression systems, the $\operatorname{scFv} \beta$ gene bearing the same signal peptide sequences (DsbA E1 and Piii E5) were sub cloned into a compatible expression plasmid ( $\mathrm{pET}$ ), and expression assessed in the most commonly used T7 RNAP expression strain, BL21(DE3) ("Methods" section). Bacterial cell cultures were grown under the same conditions, and induced for $14 \mathrm{~h}$ at $30{ }^{\circ} \mathrm{C}$. The non-riboswitch containing strains (BL21(DE3)-pET) produced $\mathrm{scFv} \beta$ in yields of 22 and $12 \mathrm{mg} / \mathrm{g} D C W$, and periplasmic secretion yields of 3.5 and $3.6 \mathrm{mg} / \mathrm{g}$ DCW for DsbA-E1 and Piii-E5 respectively, affording periplasmic secretion efficiencies of 16 and 30\% (Additional file 1: Fig. S4). The final $\mathrm{OD}_{600}$ achieved for the BL21(DE3)-pET strains was 1.5 and 3.7 with the Piii-E5 and DsbA-E1 signal peptides, compared to $\mathrm{OD}_{600} 10$ and 11 for the respective signal peptides in the BL21(LV2)-pDEST strains. This compromise in final biomass led to lower total expression and periplasmic secretion titres for $\mathrm{scFv} \beta$ in the non-riboswitch DsbA-E1 $(25.3 \pm 3.6$ and $4.5 \pm 0.7 \mathrm{mg} / \mathrm{L})$ and Piii-E5 strains $(6.2 \pm 0.5$ and $1.9 \pm 0.3 \mathrm{mg} / \mathrm{L})$. This is compared to expression and secretion titres in the BL21(LV2) DsbAE1 $(36.7 \pm 10.4$ and $26.2 \pm 7.3 \mathrm{mg} / \mathrm{L})$ and Piii-E5 strains $(101.7 \pm 31.1$ and $17.0 \pm 0.2 \mathrm{mg} / \mathrm{L}$ ) (Table 2). Regulatory control of 17 and 3-fold was observed for the DsbA-E1 and Piii-E5 signal peptide respectively in the BL21(DE3) strain. No basal expression was detected for either signal peptide in the BL21(LV2) within the western blot detection limit. This analysis was performed using a highly sensitive near infra-red fluorescent detection technique which is capable of detecting down to $50 \mathrm{pg}$ of $\operatorname{scFv} \beta$, equivalent to $0.01 \mathrm{mg} / \mathrm{L}$ based on biomass of $\mathrm{OD}_{600}=10$. In summary the BL21(LV2) strain permitted better secretion per cell (yield), better secretion efficiency, along with better biomass accumulation than the BL21(DE3) strain. The cumulative benefits of these improvements lead to a significant improvement up to ninefold increase in $\mathrm{scFv} \beta$ secretion titres.

Table 2 scFv $\beta$ expression and periplasmic secretion titres with DsbA E1 and Piii E5 signal peptides in the BL21(LV2)PDEST and BL21(DE3)-pET28 strains

\begin{tabular}{|c|c|c|c|c|}
\hline \multirow{3}{*}{$\begin{array}{l}\text { Signal peptide } \\
\text { BL21 strain }\end{array}$} & \multicolumn{4}{|l|}{ scFv $\beta$} \\
\hline & \multicolumn{2}{|l|}{ DsbA-E1 } & \multicolumn{2}{|l|}{ Piii-E5 } \\
\hline & (LV2) & (DE3) & (LV2) & DE3 \\
\hline $\begin{array}{l}\text { Expression titre } \\
\mathrm{mg} / \mathrm{L}\end{array}$ & $36.7 \pm 10.4$ & $25.3 \pm 3.6$ & $101.7 \pm 31.1$ & $6.2 \pm 0.5$ \\
\hline $\begin{array}{l}\text { Induction control } \\
\text { (max/basal) }\end{array}$ & $\geq 3666$ & 17 & $\geq 10,165$ & 3 \\
\hline $\begin{array}{l}\text { Secretion titre } \\
\mathrm{mg} / \mathrm{L}\end{array}$ & $26.2 \pm 7.3$ & $4.5 \pm 0.7$ & $17.0 \pm 0.2$ & $1.9 \pm 0.3$ \\
\hline $\mathrm{OD}_{600}$ at max & $11.0 \pm 0.3$ & $3.7 \pm 0.3$ & $10.0 \pm 0.5$ & $1.5 \pm 0.0$ \\
\hline
\end{tabular}

Performed in shaker flask induced for $14 \mathrm{~h}$ at $30^{\circ} \mathrm{C}$. No basal expression was observed in the BL21(LV2) strains, within the western blot detection limit. Induction control (max/basal) was calculated relative to the lower detection limit 

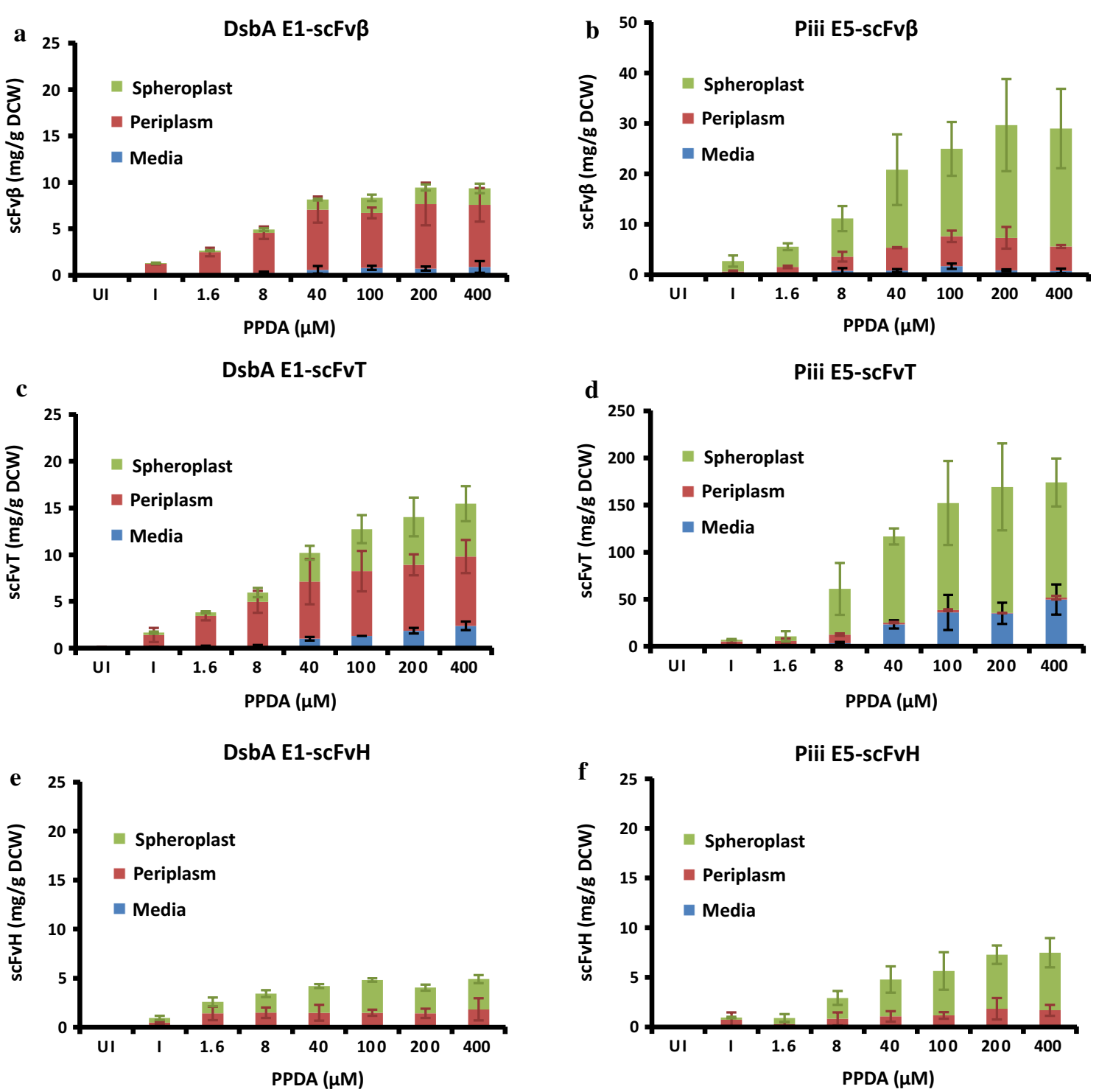

Fig. 3 Performance of different signal peptide-scFv pDEST from shake flask expression at $30^{\circ} \mathrm{C}, 14 \mathrm{~h}$ post induction. Using the DsbA E1 signal peptide sequence (a, c, e) and the Piii E5 signal peptide sequence (b, d , f) expressing scFv $\beta(\mathbf{a}-\mathbf{b})$, scFvT (c-d), and scFvH (e-f). The scFv yield plotted as $\mathrm{mg}$ per $\mathrm{g}$ dry cell weight (mg/g DCW) against inducer concentrations for different scFvs, quantified from western blot analysis, from the media (M), periplasm (PP) and spheroplast (SP) fractions. Performed in the absence of inducer (UI), or with the same IPTG (I) concentration (150 $\mu \mathrm{M})$ and increasing PPDA concentrations (1.6-400 $\mu \mathrm{M})$. All data was taken from shaker flask expression under different inducer concentrations at $30^{\circ} \mathrm{C}$, $14 \mathrm{~h}$ post induction performed in biological triplicates

\section{Codon optimised signal peptides permit tuneable expression and secretion of alternative scFv's}

To explore the modularity of both the approach and the selected signal peptides, expression and secretion of alternative single chain antibody fragments, anti-histone (scFvH) [31] and anti-tetanus (scFvT) [32] was explored (Fig. 3) (Additional file 1: Table S3 and Fig. S5). In terms of total expression, the scFv's were differently produced ranging from 5 to $16 \mathrm{mg} / \mathrm{g}$ for strains with the DsbA-E1 signal peptide to between 8 and $138 \mathrm{mg} / \mathrm{g}$ with Piii-E5. Despite this variability, rank order of $\mathrm{scFv}$ expression was maintained $(\mathrm{scFvT}>\mathrm{scFv} \beta>\mathrm{scFvH})$. All strains displayed riboswitch-dependent (IP/I) control of expression between 5 to 11 -fold, with the Piii-E5 generally outperforming the DsbA-E1. In terms of secretion, Piii-E5$\mathrm{scFvT}$ displayed the best yield but the poorest efficiency $(12.8 \mathrm{mg} / \mathrm{g}$ and $9 \%$ respectively), due to the retention of $\mathrm{scFv}$ in the spheroplast fraction. At maximal induction 
secretion efficiency was highly variable but greater efficiency was observed for SRP-dependent pathway (DsbAE1, 37-81\%) compared to the SecB-dependent pathway (Piii-E5, 9-23\%). The strains with DsbA-E1-scFvT and Piii-E5-scFv $\beta$ displayed the best riboswitch-dependent (IP/I) control of protein secretion of 7 and 13-fold respectively. Intriguingly, clear attenuation of $\operatorname{scFv} \beta$ and scFvT in periplasmic fraction is observed with DsbA-E1 up to maximum of $\sim 7 \mathrm{mg} / \mathrm{g}$ (Fig. 3a-c). However, above a certain level $(>4 \mathrm{mg} / \mathrm{g})$ greater retention of $\mathrm{scFv}$ is observed in the spheroplast fraction, indicating a system capacity overload at these higher production levels. Similarly at higher production levels $(>6 \mathrm{mg} / \mathrm{g})$ release of $\mathrm{scFv}$ into the media fraction was observed.

To verify proper post-secretion processing of the $s c F v$ from the higher producing constructs, $s c F v \beta$ and scFvT (Fig. 2a-d), intact mass spectrometry was used (Additional file 1: Fig. S6), which showed that all scFv's isolated from the periplasm, were correctly processed mature proteins (signal peptide absent), following correct signal peptidase-I processing. The scFvT isolated from the media fraction was also analysed by intact mass spectrometry and also validated the correct processing of the recombinant protein (Additional file 1: Fig. S7). The $\operatorname{scFv} \beta$ and $\operatorname{scFvT}$ proteins were also assessed by size-exclusion chromatography coupled with multiangle light scattering, this indicated that both were monomeric with apparent molecular mass values that correspond to the expected protein molecular weight (Additional file 1: Fig. S8). In order to further assess the precursor protein processing and spheroplast retention of $\operatorname{scFv} \beta$ and $\mathrm{scFvT}$, proteins located in the spheroplast and periplasm fractions were analysed by western blot, following SDS-PAGE using an extended running time to separate the protein forms (Fig. 4a-d). Analysis of DsbA $\mathrm{E} 1-\mathrm{scFv} \beta$ indicates that the target protein located in both the spheroplast and periplasm fractions has the same retention time (Fig. 4a), and the same is also observed for DsbA E1-scFvT (Fig. 4c). In contrast, analysis of Piii E5-scFv $\beta$ and Piii E5-scFvT (Fig. 4b, d) indicates the spheroplast fractions contain two species, the processed $\mathrm{scFv}$ and presumably the precursor, with the precursor being the dominant species. Due to the small difference in molecular weight between the DsbA and Piii signal peptides ( $1.99 \mathrm{vs} .2 .16 \mathrm{kDa})$, the processed and precursor forms for DsbA-dependent constructs should, in principle, be resolved by SDS-PAGE, as per the Piii-dependent constructs. On this basis, it appears possible that the spheroplast fraction for the DsbA E1-dependent samples contains the mature processed protein. The same periplasm fractions for scFv $\beta$ and scFvT were also assessed for the disulfide bond formation under reducing and non-reducing conditions (Fig. $4 \mathrm{e}-\mathrm{h}$ ). The faster migration of non-reduced samples is due to their more compact structure, which indicates correct disulfide bond formation of the scFv's within the periplasm. Finally the $\operatorname{scFv} \beta$ and $\mathrm{scFvH}$ isolated from the periplasm fraction were also analysed for binding activity to $\beta$-galactosidase and histone substrates respectively ("Methods" section), and displayed binding affinity values (Additional file 1: Fig. S9 and Fig. S10) comparable to literature values [44].

\section{Expression and secretion control performance is maintained under fed-batch fermentation}

Fed-batch fermentation experiments were performed on the ambr250 multi-parallel bio-reactor system. Initial

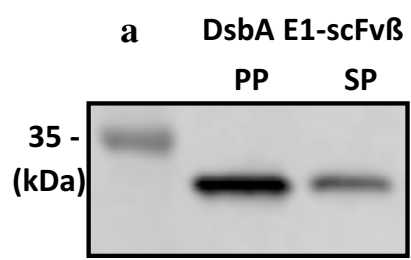

b Piii E5-scFvß

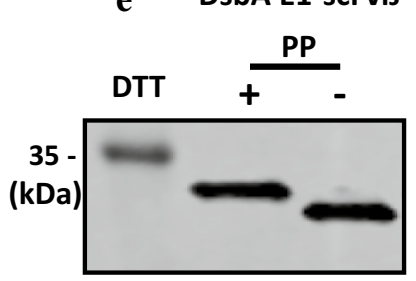

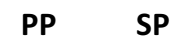

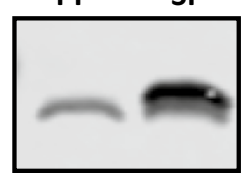

c

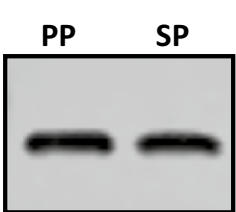

f Piii E5-scFvß

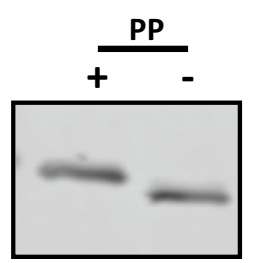

g

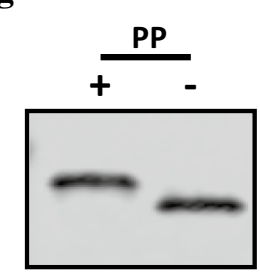

d Piii E5-scFvT

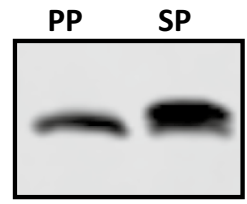

h Piii E5-scFvT

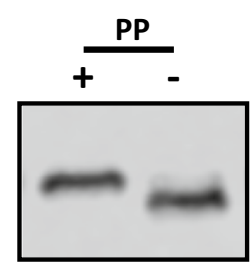

Fig. 4 Western blot analysis of the periplasm (PP) and spheroplast (SP) samples from shaker flask induction. a-d Precursor protein processing and spheroplast retention of scFv $\beta$ and scFvT were assessed with either DsbA E1 or Piii E5 signal peptide. $\mathbf{e}-\mathbf{h}$ The same periplasm fractions were also assessed for the disulfide bond formation under reducing and non-reducing conditions, with (+) or without (-) DTT 
Trial 1
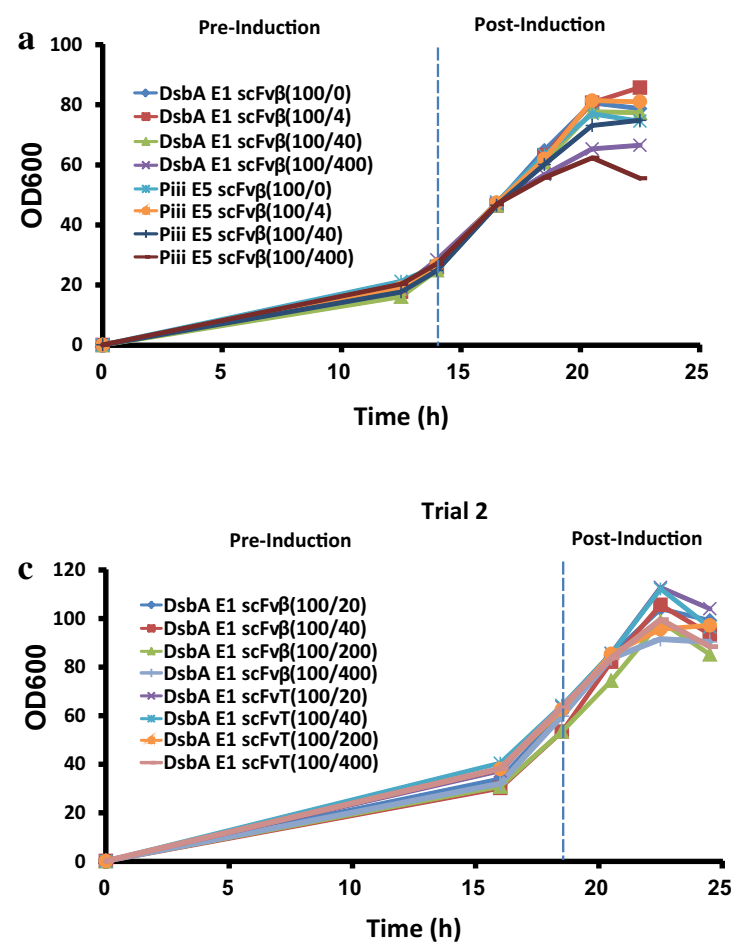

Trial $1(4 \mathrm{~h})$

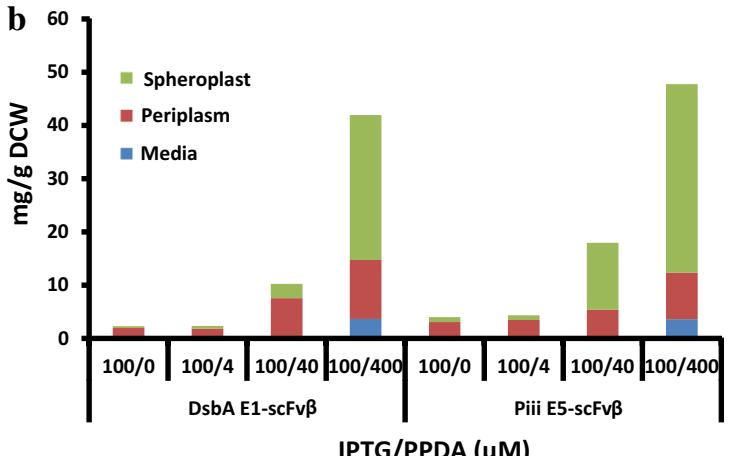

Trial $2(4 h)$

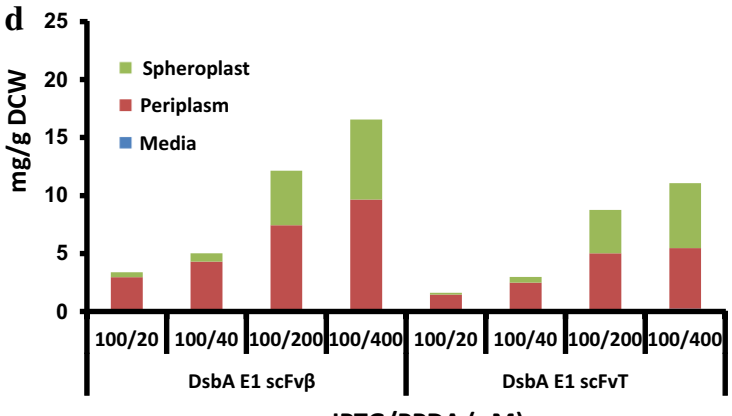

Fig. 5 Fed-batch fermentation cell growth, scFv protein yield and location. $\mathbf{a}$, b Trial 1 —scFv $\beta$ expressed with DsbA-E1 or Piii-E5 signal peptides samples collected at $4 \mathrm{~h}$ post-induction. $\mathbf{c}$, $\mathbf{d}$ Trial 2-scFv $\beta$ or scFvT expressed with DsbA-E1 signal peptide samples collected at $4 \mathrm{~h}$ post-induction. The scFv yields plotted against inducer concretion (IPTG/PPDA) fixed IPTG (100 $\mu \mathrm{M})$ and increasing PPDA concentrations $(0,4,20,40,200,400 \mu \mathrm{M})$ with scFv quantified from western blot analysis in the media (M), periplasm (PP) and spheroplast (SP) fractions. Protein production quantification was performed in technical triplicates

trials focused on $\operatorname{scFv} \beta$ production with both the DsbAE1 and Piii-E5 signal peptides in the BL21(LV2)-pDEST strain (Fig. 5a, b). Following inoculation bioreactor cultures were grown in batch mode until a sharp dissolved oxygen increase, used as an indicator of nutrient limitation, then an exponential glucose feed was initiated to achieve a specific growth rate $(\mu=0.2)$ until the end of the fermentation $(22.5 \mathrm{~h})$. The cultures were induced at $\mathrm{OD}_{600}=20-30$, with fixed IPTG $(100 \mu \mathrm{M})$ and different PPDA $(0,4,40,400 \mu \mathrm{M})$ concentrations. Following addition of inducers all cultures grew with similar growth kinetics for the first $2 \mathrm{~h}$, whilst between 4 and $6 \mathrm{~h}$ postinduction the culture with the highest concentration of inducers displayed reduced biomass accumulation (Fig. 5a). At $8 \mathrm{~h}$ post-induction the final biomass varied from $\mathrm{OD}_{600}=80$ to 50 dependent on the inducer concentration. This inverse trend between inducer concentration and final biomass was consistent with cell viability (Additional file 1: Fig. S11). Samples for $4 \mathrm{~h}$ post induction $(18 \mathrm{~h})$ were analysed for protein production and secretion (Fig. 5b, Table 3) (Additional file 1: Table S4).
Table 3 Expression, secretion titers and secretion efficiency under fed-batch fermentation

\begin{tabular}{|c|c|c|c|c|}
\hline & & & Secreted & \\
\hline & & $\mathrm{mg} / \mathrm{L}$ & $\mathrm{mg} / \mathrm{L}$ & $\%$ \\
\hline Trial 1 (4 h) & $\begin{array}{l}\text { DsbA } \\
\text { E1-ScFv } \beta\end{array}$ & $859 \pm 199$ & $248 \pm 65$ & 29 \\
\hline & Piii E5-ScFv $\beta$ & $996 \pm 117$ & $269 \pm 29$ & 27 \\
\hline Trial 2 (4 h) & $\begin{array}{l}\text { DsbA } \\
\text { E1-ScFv } \beta\end{array}$ & $572 \pm 72$ & $352 \pm 73$ & 62 \\
\hline & $\begin{array}{l}\text { DsbA } \\
\text { E1-ScFvT }\end{array}$ & $392 \pm 10$ & $210 \pm 34$ & 54 \\
\hline Trial 2 (6 h) & $\begin{array}{l}\text { DsbA } \\
\text { E1-ScFv } \beta\end{array}$ & $436 \pm 41$ & $230 \pm 28$ & 53 \\
\hline & $\begin{array}{l}\text { DsbA } \\
\text { E1-ScFvT }\end{array}$ & $417 \pm 33$ & $219 \pm 38$ & 53 \\
\hline
\end{tabular}

The highest expression level was achieved with the highest concentration of inducers (IPTG: $100 \mu \mathrm{M}$, PPDA: $400 \mu \mathrm{M})$. Similar yields and titres were observed for both strains with the Piii-E5 (51 mg/g DCW, $996 \mathrm{mg} / \mathrm{L})$ and 
DsbA-E1 (43 mg/g DCW, $859 \mathrm{mg} / \mathrm{L}$ ) signal peptides. No expression 'leak' was observed prior to induction (14 h). Induction with IPTG-only led to basal protein production in both the strains $(2-3 \mathrm{mg} / \mathrm{g} \mathrm{DCW}, 36-66 \mathrm{mg} / \mathrm{L})$. Addition of PPDA $(400 \mu \mathrm{M})$ resulted in riboswitchdependent expression control of 27-fold and 17-fold for the DsbA-E1 and Piii-E5 respectively (Fig. 5b). In terms of secretion similar yields and titres were observed, with the DsbA-E1 (12 mg/g DCW, $248 \mathrm{mg} / \mathrm{L})$ slightly outperformed by the Piii-E5 (14 mg/g DCW, $269 \mathrm{mg} / \mathrm{L})$. Secretion efficiency was slightly higher for the DsbA-E1 (29\%) than the Piii-E5 (27\%), at the highest inducer concentration. At low inducer concentration secretion efficiency increases significantly up to $80 \%$ for both DsbA E1 and Piii E5 (Fig. 5b). The scFv $\beta$ isolated from the periplasm fraction were also analysed for binding activity to $\beta$-galactosidase substrates (Methods), and displayed binding affinity values (Additional file 1: Fig. S9 and Fig. S10) comparable to literature values [44].

To further explore the secretion productivity seen with the DsbA-E1 signal peptide, another fermentation experiment was performed using the DsbA-E1 signal peptide with $\mathrm{scFv} \beta$ and $\mathrm{scFvT}$ (Fig. 5c, d). As very tight control of expression in the absence induction was observed in the initial trial, but reduced biomass accumulation was also observed for induction times $\geq 4 \mathrm{~h}$, a modified growth/induction strategy was implemented. The batchfed transition was maintained as before ("Methods" section), but cultures were induced later at $\mathrm{OD}_{600}=55-65$, with fixed IPTG $(100 \mu \mathrm{M})$ and different PPDA (20, 40, $200,400 \mu \mathrm{M})$ concentrations. Prior to induction no leaky expression was detected (Additional file 1: Table S5). Following addition of inducers all cultures grew with similar growth kinetics for the first $4 \mathrm{~h}$, attaining biomass of $\mathrm{OD}_{600}=95-110$ at $4 \mathrm{~h}$ post-induction, further induction time led to a plateau in growth and drop in biomass, possibly due to dilution with the continuous feed (Fig. 5c). Good viability was observed for all induction conditions and times (Additional file 1: Fig. S11).

The scFv $\beta$ and scFvT from the periplasm fraction were purified and analysed using intact mass spectrometry to confirm that the protein is correctly processed by cleavage of the signal peptide (Additional file 1: Fig. S7). To demonstrate the correct cell fractionation procedure an indicative coomassie stained SDS-PAGE and western blot analysis is shown (Fig. 6). Western blot analysis against the cytoplasmic specific marker (sigma 70) indicates correct fractionation, due to the absence of signal in the periplasmic fractions. Precursor protein processing and spheroplast retention of $\mathrm{scFv} \beta$ and $\mathrm{scFvT}$ were assessed by western blot, following SDS-PAGE (Additional file 1: Fig. S12). Consistent with the shake flask analysis, both DsbA E1-scFv $\beta$ and DsbA E1-scFvT from spheroplast fractions were composed of only one species. The same periplasm fractions were also assessed for disulfide bond formation under reducing and non-reducing conditions; which demonstrated disulfide bond formation for both $\mathrm{scFv} \beta$ and scFvT isolated from the periplasm (Additional file 1: Fig. S12). The highest scFv production was achieved with the highest concentration of inducers (IPTG: $100 \mu \mathrm{M}$, PPDA: $400 \mu \mathrm{M}$ ), with higher yields and titres observed for the $\operatorname{scFv} \beta(17 \mathrm{mg} / \mathrm{g} \mathrm{DCW}, 572 \mathrm{mg} / \mathrm{L})$, compared to scFvT (11 mg/g DCW, $392 \mathrm{mg} / \mathrm{L})$ at $4 \mathrm{~h}$ post-induction (Fig. 5d) (Additional file 1: Table S5 and Fig. S13). Production levels at $6 \mathrm{~h}$ for $\operatorname{scFv} \beta$ decreased slightly $(14 \mathrm{mg} / \mathrm{g}$ DCW, $436 \mathrm{mg} / \mathrm{L})$, whereas $\mathrm{scFvT}$ increased slightly ( $13 \mathrm{mg} / \mathrm{g}$ DCW, $417 \mathrm{mg} / \mathrm{L}$ ) (Additional file 1: Fig. S13 and Table S6). In terms of secretion yields and titres, $\operatorname{scFv} \beta$ had maximal production at $4 \mathrm{~h}$ post induction $(11 \mathrm{mg} / \mathrm{g} \mathrm{DCW}, 352 \mathrm{mg} / \mathrm{L})$, whereas $\mathrm{scFvT}$ had a maximal production at $6 \mathrm{~h}$ post induction $(7 \mathrm{mg} / \mathrm{g}$ DCW, $219 \mathrm{mg} / \mathrm{L}$ ) (Table 3) (Additional file 1: Table S5 and Table S6). Both displayed similar secretion efficiency (53-62\%) at the highest inducer concentration. Additionally secretion efficiency was modulated under riboswitch-dependent control, achieving up to $90 \%$ efficiency at lower inducer concentrations (Fig. 5d).

Comparing between the two fermentation trials the total production yield and titre of DsbA-E1-scFv $\beta$ were higher (2.5-fold and 1.5-fold respectively) in the initial fermentation trial (Additional file 1: Table S4 and S5). However, the second trial displayed enhanced secretion efficiency ( $29 \%$ vs. $62 \%$ ), in addition to enhanced biomass accumulation $\left(\mathrm{OD}_{600} 57\right.$ vs. 90$)$ and cell viability (CFU/ $\mathrm{mL} / \mathrm{OD} 2.4 \times 10^{9}$ vs. $8.5 \times 10^{10}$ ), this led to a similar titre for $\operatorname{scFv} \beta$ secretion from both trials ( 248 vs. $352 \mathrm{mg} / \mathrm{L}$ ). However, secreted $\mathrm{scFv}$ was all contained within the periplasm in trial 2, whereas trial 1 exhibited substantial leakage $(25 \%)$ across the outer membrane to the media fraction.

\section{Discussion}

Here we have shown that use of the multi-layered gene expression control system, RiboTite, in combination with codon optimised signal peptide sequences, permits attenuation of recombinant expression and periplasmic secretion of single chain antibody fragments (scFvs). In this study we employed the use of an orthogonal translation riboswitch control element (ORS), which releases and sequesters a RBS in the presence and absence of the small molecule inducer (PPDA) [23]. A modified T7 RNAP-dependent E. coli expression strain BL21(LV2), was developed and benchmarked for expression and control against BL21(DE3). This system uses two small molecule inducers (IPTG and PPDA) that operate at 


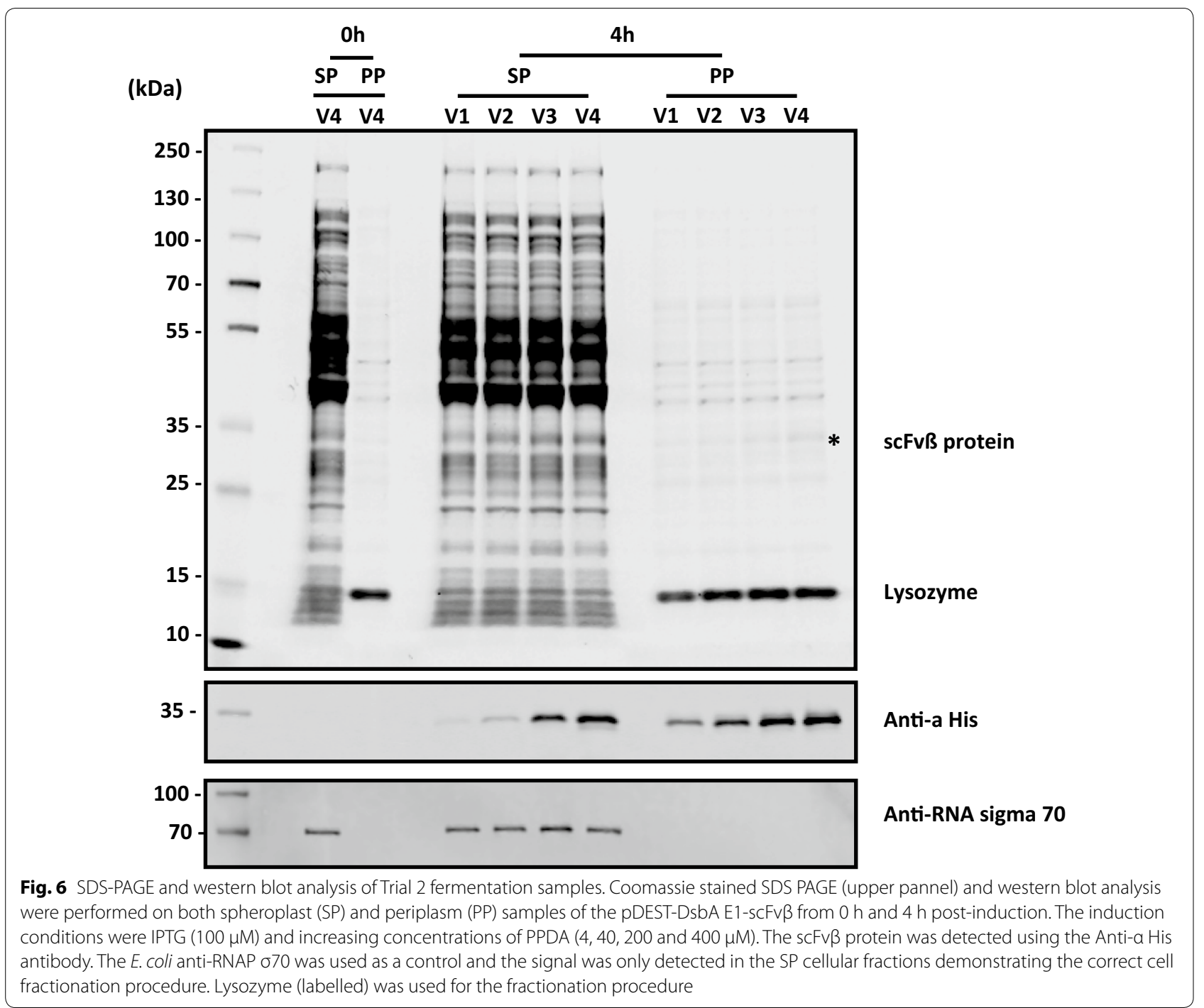

the transcriptional and translation level respectively, controlling expression of both the T7 RNAP and the gene of interest [23]. This new strain displayed excellent riboswitch-dependent control ( $>40$-fold), and extremely large small molecule-dependent (IPTG + PPDA) control of expression (>1200-fold), which as far as we are aware is an unprecedented induction dynamic range for T7 RNAP-dependent expression systems (Additional file 1: Table S1).

The exemplar gene of interest, coding for the single chain antibody fragment anti- $\beta$-galactosidase $(\operatorname{scFv} \beta)$ [30], was initially expressed as a GFP fusion protein (pENTRY) to permit the rapid selection of signal peptide sequences from a synonymous codon library (Fig. 1). Codon usage is an important feature for optimal heterologous gene expression [45], and a large number of algorithms have been developed to optimize codon usage for recombinant genes [46-49]. The $5^{\prime}$ coding region of genes for secreted proteins are known to be enriched with 'non-optimal' or rare codons [50-52]. Clustering of non-optimal codons in the $\mathrm{N}$-terminal region of the signal peptide is believed to slow the rate of translation and allow efficient engagement with secretion apparatus [51]. An alternative to this 'ramp' hypothesis is derived from the observation that non-optimal codons have a higher proportion of A-T pairs, affording transcripts with reduced local secondary structure $[37,53,54]$. For secretion of recombinant proteins, non-optimal codon usage in the signal peptide sequence has been shown to positively impact protein folding and export [33, 55]. Optimal integration of the orthogonal riboswitch (ORS) into the $5^{\prime} \mathrm{UTR}$ recently demonstrated that codon selection is determined by structural features rather than codon rarity [40]. Here in this study the codon selection method 
permitted functional context-dependent integration of orthogonal riboswitch in the $5^{\prime}$ UTR to afford a broad, inducer-dependent, dynamic range of gene expression control. The small sample size $(n=8)$ in this current study did not permit thorough statistical analysis of codon and mRNA folding metrics for the identified signal peptide sequences to support or exclude either the ramp or structural hypothesis. The selected clones included codon optimised signal peptide sequences for both the SecB-dependent (Piii-E5) and SRP-dependent (DsbAE1) pathways, permitting good riboswitch dependent (up to 16 -fold), and total (up to 127-fold) control over eGFP reporter gene expression.

Removal of the reporter fusion afforded pDEST, which demonstrated absolute control of basal expression in absence of induction and excellent dynamic range control of gene expression and secretion (Fig. 2b, Table 2). Under batch shake flask conditions $\operatorname{scFv} \beta$ was less wellexpressed and secreted with the DsbA-E1 signal peptide, however this difference in performance was reduced under fed-batch fermentation conditions (Fig. 5, Table 3). Correlation of inducible expression performance between fusion and non-fusion constructs (pENTRY vs. pDEST) indicated that dynamic range of expression control for both showed excellent linearity and good regression coefficients (slope) validating the approach and utility the pENTRY screen to select for optimal codon variants (Fig. 2c, d). Interestingly, the iterative (post-translocation) mechanism of SecB-dependent pathway was clearly demonstrated by a small regression coefficient (shallow slope) between expression of the GFP-fusion and secretion performance of the non-fusion. In the same manner comparison of the secretion efficiency and the doseresponse curves $\left(\mathrm{EC}_{50}\right)$, indicated the better coordination and coupling between expression and secretion for the SRP-dependent pathway (Additional file 1: Table S3).

When compared against the classical T7 RNAPdependent inducible promoter/operator $E$. coli expression strain, BL21(DE3), the RiboTite system permitted greater control over $\mathrm{scFv} \beta$ expression and secretion and displayed enhanced secretion titre (up to ninefold) (Additional file 1: Fig. S4). Exchange of the $\operatorname{scFv} \beta$ for alternative antibody fragments anti-histone $(\mathrm{scFvH})$ [31], and antitetanus (scFvT) [32] was performed, and these related proteins display amino acid and nucleotide sequence identity down to $87 \%$. Regulatory control was maintained for all scFvs, however, expression yields were very sensitive to the gene of interest (Fig. 3). This observation was consistent with previous reports which indicate that variability within the complementarity-determining region (CDR) of antibody fragments significantly affects production yields [56]. For each scFv protein expressed, the DsbA-E1 gave lower total expression compared to the
Piii-E5, but better secretion efficiency for both shake flask and fed-batch fermentation experiments. For all samples analysed, $\mathrm{scFv}$ isolated from the periplasm were correctly processed with disulfide bond formation and activity. For all batch and fed-batch experiments, retention of target $\mathrm{scFv}$ was observed in the spheroplast fraction. Product retained in the spheroplast for Piii-E5 (SecB) was predominately precursor protein, which had not been translocated or cleaved, indicative of an overload of the secretion pathway. However, product retained in the spheroplast for DsbA-E1 (SRP) appears to be processed mature $\mathrm{scFv}$, based on identical SDS-PAGE retention to $\mathrm{scFv}$ from the periplasm, indicating $\mathrm{scFv}$ protein insolubility in the periplasm, and/or overload of the periplasmic folding capacity. Previous studies have also shown that use of SRP-dependent signal peptide sequences increased secretion yield and efficiency of recombinant proteins, by avoiding premature cytoplasmic folding associated with the SecB-dependent pathway [10,57].

The ability to secrete recombinant proteins into the $E$. coli periplasmic compartment is limited by the periplasm size and the secretion capacity of the cell. The smaller periplasmic compartment accounts for less than $20 \%$ of the total cell volume [58]. Depending on the strain, signal peptide and protein of interest used for secretion, there is a certain threshold of the protein amount that can be exported into the periplasmic compartment. For recombinant human proinsulin, an upper secretion limit of $7.2 \mathrm{mg} / \mathrm{g} \mathrm{DCW}$ was previously reported [5]. Previous studies on the secretion of scFv's under both batch and fed-batch conditions have reported between 50 and $90 \mathrm{mg} / \mathrm{L}[10,59]$, higher values have been reported, but periplasmic titres above $>400 \mathrm{mg} / \mathrm{L}$ resulted in significant cell lysis [60]. Here, in this study under fed-batch fermentation a periplasmic secretion yield for $\mathrm{scFv} \beta$ of $14 \mathrm{mg} / \mathrm{g}$ DCW with the Piii-E5, and $12 \mathrm{mg} / \mathrm{g}$ DCW with DsbAE1 was observed (Additional file 1: Table S4). Exceeding a specific limit from each condition led to accumulation of protein in the media fraction. In our studies intact mass spectrometry analysis showed that the $\mathrm{scFv}$ protein detected in the media culture is processed correctly, the signal peptide was cleaved from the recombinant protein, indicating the protein was translocated across the inner membrane via SecYEG, and was released across the outer membrane (Additional file 1: Fig. S6). It has been recognised that recombinant protein secretion can lead to release of the protein into the cultivation media $[25,61]$. The exact mechanism is not yet known, but outer membrane protein and lipid composition have been shown to be altered during prolonged fermentation conditions $[62,63]$. It is well also known that the SecYEG-dependent secretion apparatus can easily become overloaded [17, $41,64]$. To overcome this careful optimisation is required 
to match recombinant expression rate to the secretion capacity of the host to maximise translocation efficiency. In previous studies we demonstrated, with a closely related strain, that the RiboTite system produced recombinant GFP fourfold slower (RFU/OD/hr) than the classically E. coli T7 RNAP-dependent strain, BL21(DE3), and the rate of expression could be reduced a further eightfold at lower inducer concentrations [23]. In this study the slower expression kinetics of the RiboTite system and the ability to attenuate the expression rate, permitted a range of expression rates to be assessed and matched to host secretion rate, to maximise secretion efficiency (Fig. 3).

In this study, the RiboTite system produced industrially relevant titres of scFv under fed-batch fermentation conditions. Further improvements in secretion titres could be achieved by co-expression with periplasmic chaperones and helpers. Indeed co-expression of molecular chaperones has been reported to be favourable to increase secretion of recombinant proteins by correct protein folding and/or promoting disulfide-bond formation $[3,8$, 9]. Specifically for $\mathrm{scFv}$ expression, co-expression of Skp chaperone [59, 65, 66], FkpA peptidyl-prolyl isomerase $[59,67]$, and the disulfide bond isomerase DsbC $[68,69]$ have been shown to improve recombinant protein solubility and increase titres.

\section{Conclusion}

We demonstrate that tuning gene expression, and therefore protein secretion with the RiboTite system is a viable approach for secretion of recombinant proteins. Codon optimisation of the signal peptide sequences allowed integration of the orthogonal riboswitch to permit finetuning of protein production. The RiboTite system permits (i) robust control over basal expression in absence of induction, and (ii) finely-tuned control over expression; to avoid overload of the Sec-dependent secretion pathway. Under fed-batch fermentation protein production and secretion titres of up to $1.0 \mathrm{~g} / \mathrm{L}$, and $0.35 \mathrm{~g} / \mathrm{L}$ respectively were achieved, whilst cell viability and biomass accumulation were maintained. High product titre, quality, and activity were achieved irrespective of the Secdependent pathway employed, although greater secretion efficiency was observed with the SRP pathway.

Increasing host secretion efficiency and productivity is an important cost consideration for the manufacture of recombinant antibody fragments. Enhanced protein production capability can facilitate the transition of candidate therapeutic proteins towards the clinic by limiting manufacturing failure during early stage development. Additionally reduced manufacturing costs could lessen the financial burden upon healthcare providers, and permit more equitable global access to protein-based therapeutic medicines.

\section{Methods \\ Strains, plasmids, inducers and equipment}

Expression strains: E. coli BL21 (DE3) (NEB). BL21(IL3) strain with parental BL21 genetic background, but contains an integrated orthogonal riboswitch that controls T7RNAP; BL21(LV2) similar to the BL21 (IL3), but lacks kanamycin resistance and has the $\operatorname{lacl}^{q}$ gene instead of lacI in an opposite orientation with an additional operator (O3) between the $\operatorname{lacI}^{q}$ and the promoter; and K12(LV2) similar with BL21(LV2) but with parental E. coli $\mathrm{K}-12$ W3310 genetic background. The IgG single chain antibody fragment genes (anti- $\beta$-galactosidase scFv13R4, anti-histone, and anti-tetanus toxin singlechain Fv) were synthesised by GeneART (Thermo Fisher) and sub-cloned into pENTRY and pDEST vectors, containing the kanamycin resistance marker. For strain benchmarking, the pETORS-eGFP expression vector [23] was used. For the expression in BL21(DE3) stain, the pET28 vector (no-riboswitch control), with the signal peptide and the scFv13R4 were used. For secretion constructs, synthetic DNA containing the riboswitch and signal peptide sequences (DsbA WT, PelB WT, Piii WT and yBGL2 WT) synthesized by GeneART (Thermo Fisher), and cloned upstream of the $\mathrm{scFv}$ gene by restriction digest and ligation via NdeI/SpeI sites. Inducers: IPTG (Isopropyl $\beta$-D-1-thiogalactopyranoside) (Sigma), PPDA (Pyrimido[4,5-d]pyrimidine-2,4-diamine) (Peakdale Molecular). A CLARIOstar Microplate Reader (BMG) was used to measure the eGFP fluorescence and cell density $\left(\mathrm{OD}_{600}\right)$ for intact cells.

\section{Construction of BL21(LV2) and K12(LV2) strains of E. coli}

To build on the RiboTite system for periplasmic secretion purposes, the BL21(IL3) strain [23] was modified to generate the BL21(LV2) strain for tighter secretion of recombinant proteins into the bacterial periplasm. A cassette was constructed in using the $\mathrm{pZB}$ insertion plasmid (containing chloramphenicol expression cassette flanked by two dif sites [70], modified by the addition of regions of homology to the $\mathrm{araD}$ and $\mathrm{araC}$ genes). Relative to the insertion cassette of the BL21(IL3) strain here the LacI was switched to $\operatorname{lacI}^{q}$ and the orientation was inverted. The modified cassette was amplified by PCR, and inserted by homologous recombination into the genome of $E$. coli BL21 ( $F^{-}$ompT gal dcm lon hsdSB $\left.\left(r B^{-} m B^{-}\right)\left[m a l B^{+}\right] K-12(\lambda S)\right)$, within the araC-D locus, with pSIM18 [71] to generate BL21(LV2). The same cassette was also inserted into the E. coli strain K12 W3110 (F- lambda $\left.{ }^{-} \mathrm{INV}(\mathrm{rrnD}-\mathrm{rrnE}) \mathrm{rph}-1\right)$, to generate K12(LV2). 


\section{Bacterial cell culture}

All cell cultures were grown in TB media $(2.7 \%$ yeast extract, $4.5 \%$ glycerol, $1.3 \%$ Bactotryptone) supplemented with $0.2 \%$ glucose. The cell culture for codon and strain selection assays were also grown in LB media $(0.5 \%$ yeast extract, $0.5 \% \mathrm{NaCl}, 1 \%$ Bactotryptone) with addition of $0.2 \%$ glucose. Plasmids were selected using ampicillin $(100 \mu \mathrm{g} / \mathrm{mL})$ or kanamycin $(50 \mu \mathrm{g} / \mathrm{mL})$, all purchased from Sigma. Cultures were inoculated directly from freshly plated recombinant colonies. For strain selection, pre-cultures were grown at $37{ }^{\circ} \mathrm{C}$ with shaking $(180 \mathrm{rpm})$ to an $\mathrm{OD}_{600}=0.3-0.4$, and then transferred in 96-well deep-well plates for induction. Cultures were induced for either $3 \mathrm{~h}$ at $37^{\circ} \mathrm{C}$ or $14 \mathrm{~h}$ at $30^{\circ} \mathrm{C}$ with shaking at $1000 \mathrm{rpm}$ (Stuart microtitre plate shaker incubator). To measure fluorescence, 96-well black clear bottom plates (Greiner) were used, with measurements at an Excitation $\lambda=470 \mathrm{~nm} /$ Emission $\lambda=515 \mathrm{~nm}$. For shake flask expression, pre-cultures were grown at $37{ }^{\circ} \mathrm{C}$ with shaking $(180 \mathrm{rpm})$ to reach logarithmic growth phase $\left(\mathrm{OD}_{600} \sim 0.8\right)$ and then transferred for induction in $125 \mathrm{~mL}$ shaker flasks. The volume of culture induced was $25 \mathrm{~mL}$ and cells were left un-induced (UI), induced with $150 \mu \mathrm{M}$ IPTG (I) and a combination of inducers $(150 \mu \mathrm{M}$ IPTG with varying PPDA concentrations). After induction cultures were grown at $30{ }^{\circ} \mathrm{C}$ for up to $20 \mathrm{~h}$ for pENTRY and at $14 \mathrm{~h}$ for pDEST with shaking at $210 \mathrm{rpm}$.

\section{Selection of signal peptides with synonymous codons}

Mutagenesis was performed as per the manufacturers (NEB) protocol using Phusion HF DNA Polymerase. Mutagenic libraries of the pENTRY template were generated by PCR mutagenesis with primers randomized at the wobble position at codons 2 to 6 . Dependent on the codon degeneracy of each specific amino acid, the appropriately randomised nucleotide base $(\mathrm{Y}, \mathrm{R}, \mathrm{N})$ was incorporated in the positions within the mutagenic primer, corresponding to the 3rd nucleotide for each codon, permitting generation of a synonymous codon library. The product was DpnI treated to remove the template $\left(37^{\circ} \mathrm{C}, 4 \mathrm{~h}\right)$, and transformed into Top10 F' competent E. coli cells. Individual colonies $(\mathrm{N}>10)$ were picked and screened to confirm complete template removal and library diversity. Colonies were screened to ensure 95\% coverage (threefold) of the theoretical library size, variants were selected on the basis of expanded riboswitch (PPDA) dependent control.

\section{Fractionation of E. coli}

Cultures were grown as described in "Bacterial cell cultures"-shake flask section. After specific times post induction, ODV $10\left(\mathrm{OD}_{600} * \mathrm{~mL}=10\right)$ were collected by centrifugation $\left(6000 \mathrm{~g}, 15 \mathrm{~min}, 4{ }^{\circ} \mathrm{C}\right)$ and the pellet was resuspended in $250 \mu \mathrm{L}$ Buffer $1(100 \mathrm{mM}$ Tris-acetate $\mathrm{pH}$ 8.2, $500 \mathrm{mM}$ Sucrose, $5 \mathrm{mM}$ EDTA), followed by addition of lysozyme $(0.16 \mathrm{mg} / \mathrm{mL})$ and Milli-Q water $(250 \mu \mathrm{L})$. Cells were left on ice for $5 \mathrm{~min}$ and then $\mathrm{MgSO}_{4}(20 \mathrm{mM})$ was added to stabilise the spheroplasts. The periplasm (supernatant) fractions were collected by centrifugation, while the spheroplasts (pellet) were washed once with Buffer 2 (50 mM Tris-acetate pH 8.2, $250 \mathrm{mM}$ Sucrose, $\left.10 \mathrm{mM} \mathrm{MgSO}_{4}\right)$ and resuspended in Buffer $3(50 \mathrm{mM}$ Tris-acetate pH 8.2, 2.5 mM EDTA, 0.1\% Sodium Deoxycholate and $250 \mathrm{U} / \mu \mathrm{L}$ Benzonase). Spheroplasts were lysed by freezing at $-20{ }^{\circ} \mathrm{C}$ overnight and thawing at room temperature prior to being analysed. The media and cell fractions were stored at $4{ }^{\circ} \mathrm{C}$ short-term or at $-20{ }^{\circ} \mathrm{C}$ for long-term storage. All fractions were prepared from biological triplicates.

\section{Western blot analysis}

The media, periplasm and spheroplast fractions were analysed by western blot, using an infrared imager LICOR Odyssey Sa. Samples were re-suspended in SDSPAGE loading buffer (Thermo Fisher), supplemented with $50 \mathrm{mM}$ dithiothreitol, and boiled for $10 \mathrm{~min}$. Samples were diluted to be within the linear range protein standard curve (below). Equal volumes of sample were loaded, separated by SDS-PAGE to confirm and quantify protein amounts by western blot. The membrane was then blocked with phosphate buffered saline (PBS) containing 5\% skimmed milk for $20 \mathrm{~min}(\sim 55 \mathrm{rpm}$, room temperature). The His-tagged scFv protein was detected with mouse monoclonal Anti-His antibody (Pierce, 1:3000 in PBS 5\% milk) and IRDye 680RD donkey antimouse IgG (LI-COR, 1:20,000 in PBST 5\% milk). The protein bands were visualised at $700 \mathrm{~nm}$ with the Odyssey Imaging System (LI-COR) and the signal intensity were quantified with the Image Studio 5.0 Software for densitometry analysis. Protein quantification was performed using purified recombinant scFv protein standard curves (between $50 \mathrm{pg}$ to $120 \mathrm{ng}$ ). All data were measured in biological triplicates.

\section{scFv binding assay}

The activity assay was performed using a Bio-Dot Device (Bio-Rad). A pre-wet $0.2 \mu \mathrm{m}$ nitrocellulose membrane (Amersham Hybond) was placed in the apparatus and the membrane was rehydrated with PBS. The substrates, $\beta$-galactosidase or and core histone mix (Sigma) and the negative control (bovine serum albu$\mathrm{min}$ ) were added onto the membrane diluted in Buffer $1(0.5 \mathrm{ng} / \mathrm{dot})$. The membrane was left to dry by gravity flow. A serial dilution of the periplasmic fraction containing scFv13R4 or scFvT in Buffer 1, were then added to the membrane. The membrane was left again to dry 
by gravity flow. A vacuum was applied to the apparatus to remove any excess liquid. The membrane was taken from the apparatus and was blocked for $20 \mathrm{~min}$ with $5 \%$ milk PBS (50 rpm, room temperature). His-tagged scFv13R4 or scFvT protein was detected as described above ("Western blot analysis" section). The signal intensity was quantified with the Image Studio 5.0 Software for densitometry analysis and GraphPad Prism 7 was used to for curve fitting using a four-parameter logistic function. All data were measured in biological triplicates.

\section{Fed batch fermentation}

Starter cultures were grown overnight in $25 \mathrm{~mL}$ of $\mathrm{LB}$ with $0.2 \%$ glucose and $50 \mu \mathrm{g} \cdot \mathrm{mL}^{-1}$ kanamycin at $30{ }^{\circ} \mathrm{C}$. Overnight cultures were used to inoculate $50 \mathrm{~mL}$ of LB with $0.2 \%$ glucose and $50 \mu \mathrm{g} \cdot \mathrm{mL}^{-1}$ kanamycin in a $250 \mathrm{~mL}$ baffled shake flask which was incubated at $30{ }^{\circ} \mathrm{C}$ at $200 \mathrm{rpm}$ until an $\mathrm{OD}_{600}$ of between 2 and 4 .

Fed-batch fermentations used the Ambr ${ }^{\circledR} 250$ modular (Sartorius Stedim) which comprises $250 \mathrm{~mL}$ single-use bioreactors. Fermentations started with $150 \mathrm{~mL}$ of batch medium and $100 \mathrm{~mL}$ of feed. The batch medium was from [72] and comprised batch salts $\left(14 \mathrm{~g} \cdot \mathrm{L}^{-1}\left(\mathrm{NH}_{4}\right)_{2} \mathrm{SO}_{4}\right.$, $5.5 \mathrm{~g} \cdot \mathrm{L}^{-1}$ glucose monohydrate, $20 \mathrm{~g} \cdot \mathrm{L}^{-1}$ Bacto $^{\mathrm{TM}}$ yeast extract, $2 \mathrm{~g} \cdot \mathrm{L}^{-1} \mathrm{KH}_{2} \mathrm{PO}_{4}, 16.5 \mathrm{~g} \cdot \mathrm{L}^{-1} \mathrm{~K}_{2} \mathrm{HPO}_{4}, 7.5 \mathrm{~g} \cdot \mathrm{L}^{-1}$ citric acid, $1.5 \mathrm{~mL} \cdot \mathrm{L}^{-1}$ concentrated $\mathrm{H}_{3} \mathrm{PO}_{4}$ and $\left.0.66 \mathrm{~mL} \cdot \mathrm{L}^{-1} \mathrm{PPG} 2000\right)$ and additions $\left(34 \mathrm{~mL} \cdot \mathrm{L}^{-1}\right.$ trace elements solution (comprising $3.36 \mathrm{~g} \cdot \mathrm{L}^{-1} \mathrm{FeSO}_{4} \cdot 7 \mathrm{H}_{2} \mathrm{O}$, $0.84 \mathrm{~g} \cdot \mathrm{L}^{-1} \quad \mathrm{ZnSO}_{4} \cdot 7 \mathrm{H}_{2} \mathrm{O}, \quad 0.18 \mathrm{~g} \cdot \mathrm{L}^{-1} \quad \mathrm{MnCl}_{2} \cdot 4 \mathrm{H}_{2} \mathrm{O}$, $0.25 \mathrm{~g} \cdot \mathrm{L}^{-1} \quad \mathrm{Na}_{2} \mathrm{MoO}_{4} \cdot 2 \mathrm{H}_{2} \mathrm{O}, 0.12 \mathrm{~g} \cdot \mathrm{L}^{-1} \mathrm{CuSO}^{4} \cdot 5 \mathrm{H}_{2} \mathrm{O}$, $0.36 \mathrm{~g} \cdot \mathrm{L}^{-1} \mathrm{H}_{3} \mathrm{BO}_{3}$ and $48 \mathrm{~mL} \cdot \mathrm{L}^{-1}$ concentrated $\mathrm{H}_{3} \mathrm{PO}^{4}$ ), $10 \mathrm{~mL} \cdot \mathrm{L}^{-1} 1 \mathrm{M} \mathrm{MgSO}_{4} \cdot 7 \mathrm{H}_{2} \mathrm{O}, 2 \mathrm{~mL} \cdot \mathrm{L}^{-1} 1 \mathrm{M} \mathrm{CaCl}_{2} \cdot 2 \mathrm{H}_{2} \mathrm{O}$ and $1 \mathrm{~mL} \cdot \mathrm{L}^{-1} 50 \mathrm{mg} \cdot \mathrm{mL}^{-1}$ kanamycin stock). The feed solution comprised $220 \mathrm{~g} \cdot \mathrm{L}^{-1}$ glucose monohydrate (Trial 1-FBF) or $440 \mathrm{~g} \cdot \mathrm{L}^{-1}$ glucose monohydrate (Trial 2-FBF), $30 \mathrm{~mL} \cdot \mathrm{L}^{-1} 1 \mathrm{M} \mathrm{MgSO}{ }_{4} \cdot 7 \mathrm{H}_{2} \mathrm{O}$, and $1 \mathrm{~mL} \cdot \mathrm{L}^{-1}$ $50 \mathrm{mg} \cdot \mathrm{mL}^{-1}$ kanamycin. Batch salts were sterilised by autoclaving. All other culture medium components were filter sterilised and added to the fermentation vessels before use. The $\mathrm{pH}$ was maintained at 6.8 using $10 \%$ $\mathrm{NH}_{4} \mathrm{OH}$ and $1 \mathrm{M} \mathrm{HCl}$. Polypropylene glycol (PPG 2 000) was used as antifoam. The dissolved oxygen (DOT) was maintained at above $20 \%$ when possible, using cascade control (increasing the stirrer speed followed by an increase in the air flow rate, and if not sufficient, by addition of $\mathrm{O}_{2}$ ). Bioreactors were inoculated to an $\mathrm{OD}_{600}$ of 0.1. Exponential feeding was used according to Eq. 1.

$$
F=\left(\frac{1}{S}\right) \times\left(\frac{\mu}{Y_{X S}}+m\right) \times X_{0} \times e^{\mu t}
$$

where $F$ is the feed rate in $\mathrm{L} \cdot \mathrm{h}^{-1}, S$ is the substrate concentration in the feed (depending on the fermentation run, $220 \mathrm{~g} \cdot \mathrm{L}^{-1}$ or $440 \mathrm{~g} \cdot \mathrm{L}^{-1}$ glucose monohydrate), $\mu$ is the required specific growth rate $\left(0.2 \mathrm{~h}^{-1}\right), \mathrm{Y}_{X S}$ is the yield coefficient ( $0.365 \mathrm{~g}$ biomass per g glucose), $m$ is the maintenance coefficient (0.0468), $\mathrm{X}_{0}$ is the biomass in $\mathrm{g}$ at the start of the feed and $t$ is time. The feed was started when the DO increased, indicating nutrient limitation.

\section{Cell viability assay (CFU)}

Culture samples taken post-induction were serially diluted in PBS and plated onto LB agar to evaluate cell culturability, used as an indication of cell viability. LB agar plates were incubated at $37^{\circ} \mathrm{C}$ overnight.

\section{Data processing and statistical analysis}

Data was processed and analysed using Microsoft Excel, GraphPad Prism7 and OriginPro 8.5.1. Each data point used for analysis was from three biological experimental repeats and was used for fitting a logistic growth curve. The $\mathrm{EC}_{50}$ value represents the amount of PPDA needed to achieve half of the maximum induction response. Error bars represent calculated standard deviations. For western blot quantification, the Image Studio 5.0 Software was used for densitometry analysis. A calibration curve was constructed using 3 up to $6 \mathrm{scFv}$ standards. Data was fitted using linear regression into a straight line and the linear equation from the $\mathrm{scFv}$ calibration curve was used to normalise and convert the western blot sample into ng of protein. The measured $\mathrm{OD}_{600}$ were used to normalise and calculate the $\mathrm{mg} / \mathrm{g}$ of dry cell weight. Dry cell weight was determined, by collecting culture in dry pre-weighed $2 \mathrm{~mL}$ tubes; the samples were centrifuged $10 \mathrm{~min}$ at $6000 \mathrm{~g}$, cell pellets were dried at $100{ }^{\circ} \mathrm{C}$ for $48 \mathrm{~h}$ and tubes re-weighed, replicate values were used to determine an OD to g DCW conversion factor $(0.35 \mathrm{mg} /$ $\mathrm{mL})$. Subsequently, the dry cell weight of the $E$. coli cell was calculated as the $\mathrm{OD}_{600}$ multiplied by conversion factor $(0.35 \mathrm{mg} / \mathrm{mL})$. Linear regression was employed to analyse correlation at $30{ }^{\circ} \mathrm{C}$ induction between pENTRY and pDEST (secretion and expression). The relationship between western blot data and dot blot data was again investigated by linear regression. Semilog regression analysis evaluated the relationship between PENTRY and pDEST. Pearson's correlation coefficient and the best-fit line were calculated. $\mathrm{P}<0.05$ was considered statistically significant.

\section{Protein purification}

All $s c F v$ proteins expressed have a hexa-histidine tag to allow purification by standard immobilized metal affinity chromatography (IMAC) using HisPur ${ }^{\mathrm{TM}} \mathrm{Ni}-\mathrm{NTA}$ 
Resin (ThermoFisher). The proteins used as standard for western blot quantification were purified using whole cell lysates from cell cultures expressing the genes of interest ("Bacterial cell culture"). Cell pellets were collected by centrifugation ( $9000 \mathrm{~g}$ for $30 \mathrm{~min}$ ) and resuspended in lysis buffer $(50 \mathrm{mM}$ Tris $\mathrm{HCl} \mathrm{pH} \mathrm{7.5,500} \mathrm{mM} \mathrm{NaCl}$, $10 \mathrm{mM}$ imidazole) supplemented with EDTA-free protease inhibitor (Roche), DNAase $(10 \mathrm{U} / \mathrm{mL})$ and lysozyme $(1 \mathrm{mg} / \mathrm{mL})$. Cells were sonicated and the supernatant was collected by high-speed centrifugation $(42,000 g)$. Supernatant was incubated with the Ni-NTA beads for at least $1 \mathrm{~h}$ at $4{ }^{\circ} \mathrm{C}$. Protein was washed $3 \times$ times with lysis buffer and then eluted with $100 \mathrm{mM}$ imidazole. Protein was then concentrated using 5000 MWCO Vivaspin centrifugal units and then dialysed with dialysis buffer $(25 \mathrm{mM}$ Tris $\mathrm{HCl} \mathrm{pH} \mathrm{7.5,} 50 \mathrm{mM} \mathrm{NaCl}$ ). Protein purity was assessed by SDS-PAGE and its concentration determined using NanoDrop 2000 Spectophotometer and extinction coefficient. Protein was stored at $-80^{\circ} \mathrm{C}$.

\section{Intact mass spectrometry}

A 1200 series Agilent LC was used to inject $5 \mu \mathrm{L}$ of sample into $5 \%$ acetonitrile ( $0.1 \%$ formic acid) and desalted inline. This was eluted over $1 \mathrm{~min}$ by $95 \%$ acetonitrile. The resulting multiply charged spectrum was analysed by an Agilent QTOF 6510, and deconvoluted using Agilent Masshunter Software.

\section{Size-exclusion chromatography coupled with multi-angle light scattering (SEC-MALS) analysis}

Samples were loaded onto a Superdex 75 26/600 column (GE healthcare) pre-equilibrated in protein dialysis buffer (25 mM Tris $\mathrm{pH} 7.5,50 \mathrm{mM} \mathrm{NaCl}$ ) running at a flow rate of $0.75 \mathrm{~mL} / \mathrm{min}$. Samples were analysed using a DAWN Wyatt HeliosII 18-angle laser photometer, with an additional Wyatt QELS detector. This was coupled to a Wyatt Optilab rEX refractive index detector and the molecular mass moments, polydispersity, and concentrations of the resulting peaks were analysed using Astra 6.1 software (Wyatt, Santa Barbara, USA).

\section{Additional file}

Additional file 1. Additional figures and tables.

\section{Authors' contributions}

LGH performed experiments, analysed data, compiled figures, and wrote the manuscript. SH performed experiments and analysed data. TSC performed experiments. CJW performed experiments. CFROM performed experiments. DSY performed experiments. RK analysed data. RM analysed data. SGW planned experiments. DCS planned the project. ND planned the project, analysed data, and wrote the manuscript. All authors read and approved the final manuscript.

\section{Author details}

${ }^{1}$ Manchester Institute of Biotechnology, School of Chemistry, University of Manchester, Manchester M1 7DN, UK. ${ }^{2}$ Cobra Biologics Ltd, Keele ST5 5SP, UK.

\section{Acknowledgements}

We thank Thomas Jowitt and the Biomolecular Analysis Core Facility for help with the SEC-MALS experiment and analysis, Reynard Spiess for help with the intact mass analysis, and Kate Young for help with construction of the expression strains, and Anthony Hitchcock for initiating early project discussions.

\section{Competing interests}

ND holds a patent covering the use and application of the expression technology employed here.

\section{Availability of data and materials}

All data generated or analyzed in this study are included in this manuscript or in Additional files. Raw data are available from the corresponding author upon reasonable request.

\section{Consent for publication}

Not applicable.

Ethics approval and consent to participate

Not applicable.

\section{Funding}

This research was funded by an IB Catalyst Award, PeriTune-a clonal optimisation platform, from the UKRI research councils BBSRC (BB/M011259/1) and Innovate UK (131836). Additionally L.G.H. is supported by EPSRC CDT grant (EP/I033270/1). R.K. is supported by BBSRC DTP grant (BB/M011208/1). RM is supported BB/K014773/1 and N.D. holds a BBSRC David Phillips fellowship BB/ K014773/1.

\section{Publisher's Note}

Springer Nature remains neutral with regard to jurisdictional claims in published maps and institutional affiliations.

Received: 7 September 2018 Accepted: 14 December 2018

Published online: 22 December 2018

References

1. Bentley WE, Mirjalili N, Andersen DC, Davis RH, Kompala DS. Plasmidencoded protein: the principal factor in the "metabolic burden" associated with recombinant bacteria. Biotechnol Bioeng. 1990;35:668-81.

2. Glick BR. Metabolic load and heterologous gene expression. Biotechnol Adv. 1995;13:247-61.

3. Baneyx F, Mujacic M. Recombinant protein folding and misfolding in Escherichia coli. Nat Biotechnol. 2004;22:1399-408.

4. Dong H, Nilsson L, Kurland CG. Gratuitous overexpression of genes in Escherichia coli leads to growth inhibition and ribosome destruction. J Bacteriol. 1995:177:1497-504.

5. Mergulhao FJ, Taipa MA, Cabral JM, Monteiro GA. Evaluation of bottlenecks in proinsulin secretion by Escherichia coli. J Biotechnol. 2004; 109:31-43.

6. Ferrer-Miralles N, Domingo-Espin J, Corchero JL, Vazquez E, Villaverde A. Microbial factories for recombinant pharmaceuticals. Microb Cell Fact. 2009;8:17

7. Gasser B, Saloheimo M, Rinas U, Dragosits M, Rodriguez-Carmona E, Baumann K, Giuliani M, Parrilli E, Branduardi P, Lang C, et al. Protein folding and conformational stress in microbial cells producing recombinant proteins: a host comparative overview. Microb Cell Fact. 2008;7:11.

8. de Marco A. Strategies for successful recombinant expression of disulfide bond-dependent proteins in Escherichia coli. Microb Cell Fact. 2009;8:26. 
9. Makino T, Skretas G, Georgiou G. Strain engineering for improved expression of recombinant proteins in bacteria. Microb Cell Fact. 2011;10:32.

10. Lee YJ, Jeong KJ. Enhanced production of antibody fragment via SRP pathway engineering in Escherichia coli. Biotechnol Bioprocess Eng. 2013:18:751-8.

11. Mulder KC, Bandola J, Schumann W. Construction of an artificial secYEG operon allowing high level secretion of alpha-amylase. Protein Expr Purif. 2013;89:92-6.

12. Costa TR, Felisberto-Rodrigues C, Meir A, Prevost MS, Redzej A, Trokter M, Waksman G. Secretion systems in Gram-negative bacteria: structural and mechanistic insights. Nat Rev Microbiol. 2015;13:343-59.

13. Freudl R. Signal peptides for recombinant protein secretion in bacterial expression systems. Microb Cell Fact. 2018;17:52.

14. Tsirigotaki A, De Geyter J, Sostaric N, Economou A, Karamanou S. Protein export through the bacterial Sec pathway. Nat Rev Microbiol. 2017;15:21-36.

15. Papanikou E, Karamanou S, Economou A. Bacterial protein secretion through the translocase nanomachine. Nat Rev Microbiol. 2007:5:839-51.

16. Feilmeier BJ, Iseminger G, Schroeder D, Webber H, Phillips GJ. Green fluorescent protein functions as a reporter for protein localization in Escherichia coli. J Bacteriol. 2000;182:4068-76.

17. Simmons LC, Yansura DG. Translational level is a critical factor for the secretion of heterologous proteins in Escherichia coli. Nat Biotechnol. 1996;14:629-34.

18. Lee YJ, Jeong KJ. Challenges to production of antibodies in bacteria and yeast. J Biosci Bioeng. 2015;120:483-90

19. Khlebnikov A, Keasling JD. Effect of lacY expression on homogeneity of induction from the P-tac and P-trc promoters by natural and synthetic inducers. Biotechnol Prog. 2002;18:672-4.

20. Morgan-Kiss RM, Wadler C, Cronan JE. Long-term and homogeneous regulation of the Escherichia coli araBAD promoter by use of a lactose transporter of relaxed specificity. Proc Natl Acad Sci U S A. 2002;99:7373-7.

21. Marschall L, Sagmeister P, Herwig C. Tunable recombinant protein expression in E. coli: enabler for continuous processing? Appl Microbiol Biotechnol. 2016;100:5719-28.

22. Muhamadali H, XuY, Morra R, Trivedi DK, Rattray NJW, Dixon N, Goodacre R. Metabolomic analysis of riboswitch containing E-coli recombinant expression system. Mol BioSyst. 2016;12:350-61.

23. Morra R, Shankar J, Robinson CJ, Halliwell S, Butler L, Upton M, Hay S, Micklefield J, Dixon N. Dual transcriptional-translational cascade permits cellular level tuneable expression control. Nucleic Acids Res. 2016;44:e21.

24. Low KO, Muhammad Mahadi N, Md Illias R. Optimisation of signal peptide for recombinant protein secretion in bacterial hosts. Appl Microbiol Biotechnol. 2013;97:3811-26.

25. Mergulhao FJ, Summers DK, Monteiro GA. Recombinant protein secretion in Escherichia coli. Biotechnol Adv. 2005;23:177-202.

26. Holliger P, Hudson PJ. Engineered antibody fragments and the rise of single domains. Nat Biotechnol. 2005;23:1126-36.

27. Saeed AF, Wang R, Ling S, Wang S. Antibody engineering for pursuing a healthier future. Front Microbiol. 2017:8:495.

28. Kaplon H, Reichert JM. Antibodies to watch in 2018. MAbs. 2018;10:183-203.

29. Nelson AL. Antibody fragments: hope and hype. MAbs. 2010;2:77-83.

30. Martineau P, Jones P, Winter G. Expression of an antibody fragment at high levels in the bacterial cytoplasm. J Mol Biol. 1998;280:117-27.

31. Philibert P, Stoessel A, Wang W, Sibler AP, Bec N, Larroque C, Saven JG, Courtete J, Weiss E, Martineau P. A focused antibody library for selecting scFvs expressed at high levels in the cytoplasm. BMC Biotechnol. 2007;7:81.

32. Scott N, Reynolds CB, Wright MJ, Qazi O, Fairweather N, Deonarain MP. Single-chain Fv phage display propensity exhibits strong positive correlation with overall expression levels. BMC Biotechnol. 2008:8:97.

33. Humphreys DP, Sehdev M, Chapman AP, Ganesh R, Smith BJ, King LM, Glover DJ, Reeks DG, Stephens PE. High-level periplasmic expression in Escherichia coli using a eukaryotic signal peptide: importance of codon usage at the $5^{\prime}$ end of the coding sequence. Protein Expr Purif. 2000;20:252-64.
34. Thie H, Schirrmann T, Paschke M, Dubel S, Hust M. SRP and Sec pathway leader peptides for antibody phage display and antibody fragment production in E. coli. N Biotechnol. 2008;25:49-54.

35. Cardinale S, Arkin AP. Contextualizing context for synthetic biologyidentifying causes of failure of synthetic biological systems. Biotechnol J. 2012;7:856-66

36. Mutalik VK, Guimaraes JC, Cambray G, Lam C, Christoffersen MJ, Mai QA, Tran AB, Paull M, Keasling JD, Arkin AP, Endy D. Precise and reliable gene expression via standard transcription and translation initiation elements. Nat Methods. 2013;10:354-60.

37. Goodman DB, Church GM, Kosuri S. Causes and effects of N-terminal codon bias in bacterial genes. Science. 2013;342:475-9.

38. Salis HM, Mirsky EA, Voigt CA. Automated design of synthetic ribosome binding sites to control protein expression. Nat Biotechnol. 2009;27:946-50.

39. Tuller T, Carmi A, Vestsigian K, Navon S, Dorfan Y, Zaborske J, Pan T, Dahan $\mathrm{O}$, Furman I, Pilpel Y. An evolutionarily conserved mechanism for controlling the efficiency of protein translation. Cell. 2010;141:344-54.

40. Kent R, Halliwell S, Young K, Swainston N, Dixon N. Rationalizing contextdependent performance of dynamic RNA regulatory devices. ACS Synth Biol. 2018. https://doi.org/10.1021/acssynbio.8b00041.

41. Schlegel S, Rujas E, Ytterberg AJ, Zubarev RA, Luirink J, de Gier JW. Optimizing heterologous protein production in the periplasm of $E$. coli by regulating gene expression levels. Microb Cell Fact. 2013;12:24.

42. Klumpp S, Scott M, Pedersen S, Hwa T. Molecular crowding limits translation and cell growth. Proc Natl Acad Sci U S A. 2013;110:16754-9.

43. Nystrom A, Papachristodoulou A, Angel A. A dynamic model of resource allocation in response to the presence of a synthetic construct. ACS Synth Biol. 2018;7:1201-10.

44. Bach H, Mazor Y, Shaky S, Shoham-Lev A, Berdichevsky Y, Gutnick DL, Benhar I. Escherichia coli maltose-binding protein as a molecular chaperone for recombinant intracellular cytoplasmic single-chain antibodies. J Mol Biol. 2001;312:79-93.

45. Gustafsson C, Govindarajan S, Minshull J. Codon bias and heterologous protein expression. Trends Biotechnol. 2004;22:346-53.

46. Tian J, Yan Y, Yue Q, Liu X, Chu X, Wu N, Fan Y. Predicting synonymous codon usage and optimizing the heterologous gene for expression in $E$. coli. Sci Rep. 2017;7:9926.

47. Boel G, Letso R, Neely H, Price WN, Wong KH, Su M, Luff J, Valecha M, Everett JK, Acton TB, et al. Codon influence on protein expression in E. coll correlates with mRNA levels. Nature. 2016;529:358-63.

48. Grote A, Hiller K, Scheer M, Munch R, Nortemann B, Hempel DC, Jahn D. $J$ Cat: a novel tool to adapt codon usage of a target gene to its potential expression host. Nucleic Acids Res. 2005;33:W526-31.

49. Sabi R, Volvovitch Daniel R, Tuller T. stAlcalc: tRNA adaptation index calculator based on species-specific weights. Bioinformatics. 2017;33:589-91.

50. Zalucki YM, Beacham IR, Jennings MP. Biased codon usage in signal peptides: a role in protein export. Trends Microbiol. 2009;17:146-50.

51. Tuller T, Zur H. Multiple roles of the coding sequence $5^{\prime}$ end in gene expression regulation. Nucleic Acids Res. 2015;43:13-28.

52. Pechmann S, Chartron JW, Frydman J. Local slowdown of translation by nonoptimal codons promotes nascent-chain recognition by SRP in vivo. Nat Struct Mol Biol. 2014:21:1100-5.

53. Keller TE, Mis SD, Jia KE, Wilke CO. Reduced mRNA secondary-structure stability near the start codon indicates functional genes in prokaryotes. Genome Biol Evol. 2012:4:80-8.

54. Kudla G, Murray AW, Tollervey D, Plotkin JB. Coding-sequence determinants of gene expression in Escherichia coli. Science. 2009;324:255-8.

55. Zalucki YM, Shafer WM, Jennings MP. Directed evolution of efficient secretion in the SRP-dependent export of TolB. Biochim Biophys Acta. 2011;1808:2544-50.

56. Gaciarz A, Ruddock LW. Complementarity determining regions and frameworks contribute to the disulfide bond independent folding of intrinsically stable scFv. PLOS ONE. 2017:12:e0189964.

57. Steiner D, Forrer P, Stumpp MT, Pluckthun A. Signal sequences directing cotranslational translocation expand the range of proteins amenable to phage display. Nat Biotechnol. 2006;24:823-31.

58. Graham LL, Beveridge TJ, Nanninga N. Periplasmic space and the concept of the periplasm. Trends Biochem Sci. 1991;16:328-9. 
59. Sonoda H, Kumada Y, Katsuda T, Yamaji H. Effects of cytoplasmic and periplasmic chaperones on secretory production of single-chain Fv antibody in Escherichia coli. J Biosci Bioeng. 2011;111:465-70.

60. Sletta H, Nedal A, Aune TE, Hellebust H, Hakvag S, Aune R, Ellingsen TE, Valla S, Brautaset T. Broad-host-range plasmid pJB658 can be used for industrial-level production of a secreted host-toxic single-chain antibody fragment in Escherichia coli. Appl Environ Microbiol. 2004;70:7033-9.

61. Morra R, Del Carratore F, Muhamadali H, Horga LG, Halliwell S, Goodacre $\mathrm{R}$, Breitling $\mathrm{R}$, Dixon N. Translation stress positively regulates MscLdependent excretion of cytoplasmic proteins. MBio. 2018. https://doi. org/10.1128/mBio.02118-17.

62. Backlund E, Reeks D, Markland K, Weir N, Bowering L, Larsson G. Fedbatch design for periplasmic product retention in Escherichia coli. J Biotechnol. 2008;135:358-65.

63. Shokri A, Sanden AM, Larsson G. Growth rate-dependent changes in Escherichia coli membrane structure and protein leakage. Appl Microbiol Biotechnol. 2002;58:386-92.

64. Baumgarten T, Ytterberg AJ, Zubarev RA, de Gier JW. Optimizing recombinant protein production in the Escherichia coli periplasm alleviates stress. Appl Environ Microbiol. 2018. https://doi.org/10.1128/AEM.00270-18.

65. Mavrangelos C, Thiel M, Adamson PJ, Millard DJ, Nobbs S, Zola H, Nicholson IC. Increased yield and activity of soluble single-chain antibody fragments by combining high-level expression and the Skp periplasmic chaperonin. Protein Expr Purif. 2001;23:289-95.

66. Wang R, Xiang S, Feng Y, Srinivas S, Zhang Y, Lin M, Wang S. Engineering production of functional scFv antibody in E. coli by co-expressing the molecule chaperone Skp. Front Cell Infect Microbiol. 2013;3:72.
67. Levy R, Ahluwalia K, Bohmann DJ, Giang HM, Schwimmer LJ, Issafras H, Reddy NB, Chan C, Horwitz AH, Takeuchi T. Enhancement of antibody fragment secretion into the Escherichia coli periplasm by co-expression with the peptidyl prolyl isomerase, FkpA, in the cytoplasm. J Immunol Methods. 2013;394:10-21.

68. Groff D, Armstrong S, Rivers PJ, Zhang J, Yang J, Green E, Rozzelle J, Liang $\mathrm{S}$, Kittle JD Jr, Steiner AR, et al. Engineering toward a bacterial "endoplasmic reticulum" for the rapid expression of immunoglobulin proteins. MAbs. 2014;6:671-8.

69. Sun XW, Wang XH, Yao YB. Co-expression of Dsb proteins enables soluble expression of a single-chain variable fragment (scFv) against human type 1 insulin-like growth factor receptor (IGF-1R) in E. coli. World J Microbiol Biotechnol. 2014;30:3221-7.

70. Bloor AE, Cranenburgh RM. An efficient method of selectable marker gene excision by Xer recombination for gene replacement in bacterial chromosomes. Appl Environ Microbiol. 2006;72:2520-5.

71. Chan W, Costantino N, Li R, Lee SC, Su Q, Melvin D, Court DL, Liu P. A recombineering based approach for high-throughput conditional knockout targeting vector construction. Nucleic Acids Res. 2007;35:e64.

72. Want A, Thomas OR, Kara B, Liddell J, Hewitt CJ. Studies related to antibody fragment (Fab) production in Escherichia coli W3110 fed-batch fermentation processes using multiparameter flow cytometry. Cytometry A. $2009 ; 75: 148-54$
Ready to submit your research? Choose BMC and benefit from:

- fast, convenient online submission

- thorough peer review by experienced researchers in your field

- rapid publication on acceptance

- support for research data, including large and complex data types

- gold Open Access which fosters wider collaboration and increased citations

- maximum visibility for your research: over 100M website views per year

At BMC, research is always in progress.

Learn more biomedcentral.com/submissions 